\title{
The biostratigraphy of the Upper Pliensbachian-Toarcian (Lower Jurassic) sequence at Ilminster, Somerset
}

\author{
I. BOOMER ${ }^{1, *}$, A. R. LORD ${ }^{2}$, K. N. PAGE ${ }^{3}$, P. R. BOWN 4 , F. M. D. LOWRY ${ }^{5}$ \& J. B. RIDING \\ ${ }^{1}$ School of Geography, Earth and Environmental Sciences, University of Birmingham, B15 2TT, UK \\ ${ }^{2}$ Forschungsinstitut Senckenberg, Senckenberganlage 25, Frankfurt-am-Main, Germany \\ ${ }^{3}$ SEOES, University of Plymouth, Drake Circus, Plymouth PL4 8AA, UK \\ ${ }^{4}$ Department of Geological Sciences, University College London, Gower Street, London WC1E 6BT, UK \\ ${ }^{5}$ School of Earth \& Environmental Sciences, University of Greenwich, Chatham Maritime, Kent ME4 4AW, UK \\ ${ }^{6}$ British Geological Survey, Keyworth, Nottinghamshire NG12 5GG, UK \\ *Corresponding author (e-mail: i.boomer@bham.ac.uk)
}

\begin{abstract}
Temporary road sections for the A303 bypass at Ilminster, Somerset, revealed Upper Pliensbachian and Toarcian sediments from an alternating limestone-marl facies, in marked contrast to the limestone-dominated Dorset coast succession. The lithostratigraphy is described, with the standard ammonite zonation providing chronostratigraphical correlation. The uppermost Pliensbachian (Spinatum Chronozone) and much of the Toarcian (Serpentinum, Bifrons, Variabilis, Thouarsense and Pseudoradiosa chronozones) of the classic Dorset coast Lower Jurassic sequence are represented by the Beacon Limestone Formation, formerly the 'Junction Bed' (a highly condensed carbonate deposit). The Tenuicostatum Chronozone is largely missing from the sequence. Elsewhere in southern and eastern England this interval is poorly or rarely exposed. The argillaceous units have yielded rich microfaunas and -floras (foraminifera, ostracods, calcareous nannofossils and palynomorphs), the biostratigraphical distributions of which are analysed and discussed in relation to contemporary evolutionary patterns and other UK records. This study provides an insight into the micro-biostratigraphy of the Late Pliensbachian to Toarcian interval for onshore southern England. J. Micropalaeontol. 28(1): 67-85, May 2009.
\end{abstract}

KEYWORDS: Pliensbachian-Toarcian, Ostracoda, Foraminifera, palynology, nannofossils

\section{INTRODUCTION}

In 1987, roadworks near Seavington St Michael, in connection with the construction of the A303 Ilminster bypass (Fig. 1), created new exposures of the Beacon Limestone Formation, providing an opportunity to study and sample this generally poorly exposed unit. In contrast with earlier studies of the Beacon Limestone Formation, these sections were the subject of detailed micropalaeontological sampling. Preliminary studies of the bypass site commenced in connection with a joint archaeological and geological survey co-ordinated by $\mathrm{Mr} \mathrm{R}$. A. Croft (Somerset County Council). By early 1988, however, little exposure remained, and the sections described in Appendix A herein had been largely covered by soil and seeded. A small exposure of the succession was, however, left clear and remained only poorly visible in 1999. The former exposures are described in detail in Appendix A; their location is shown in Figure 1, while Figure 2 illustrates the sedimentary record of the two sections sampled at Ilminster. The sequence is clearly condensed and the ammonite evidence for the Tenuicostatum Chronozone suggests that it is, at best, highly condensed and there may be breaks in sedimentation within the earliest Toarcian horizons.

The occurrence of ostracods from this section was published previously separately (Boomer, 1992), while Bown \& Cooper (1989) made taxonomic observations on some of the calcareous nannofossils recorded at Ilminster. This is the first attempt to synthesize microfaunal events and biostratigraphy in this sequence.

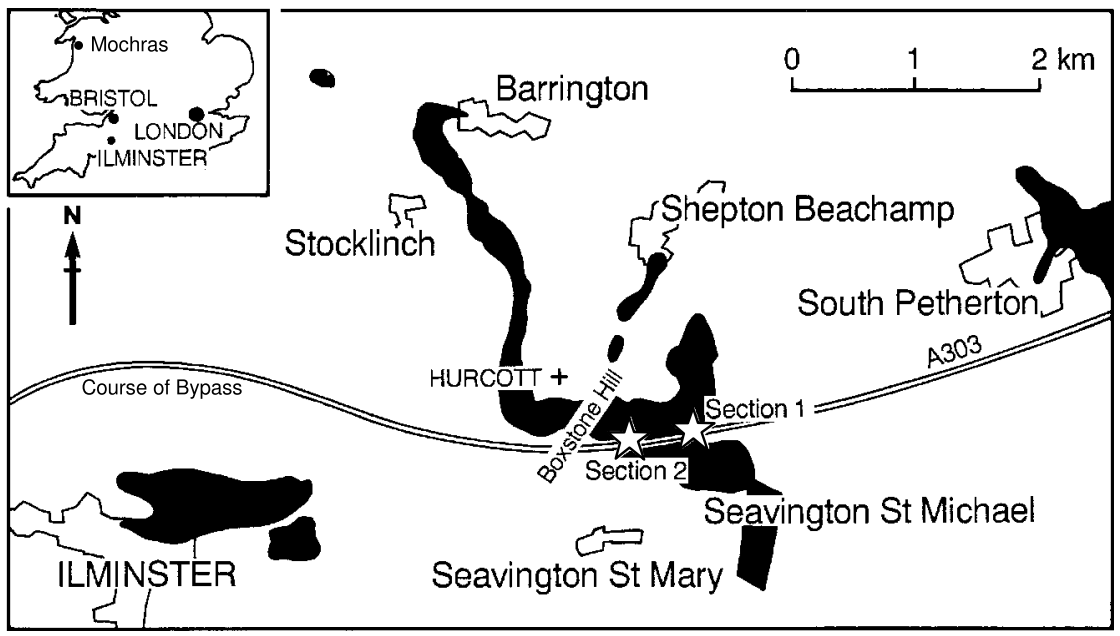

Fig. 1. Location map of the Ilminster exposures (in black), key sections marked by stars. 


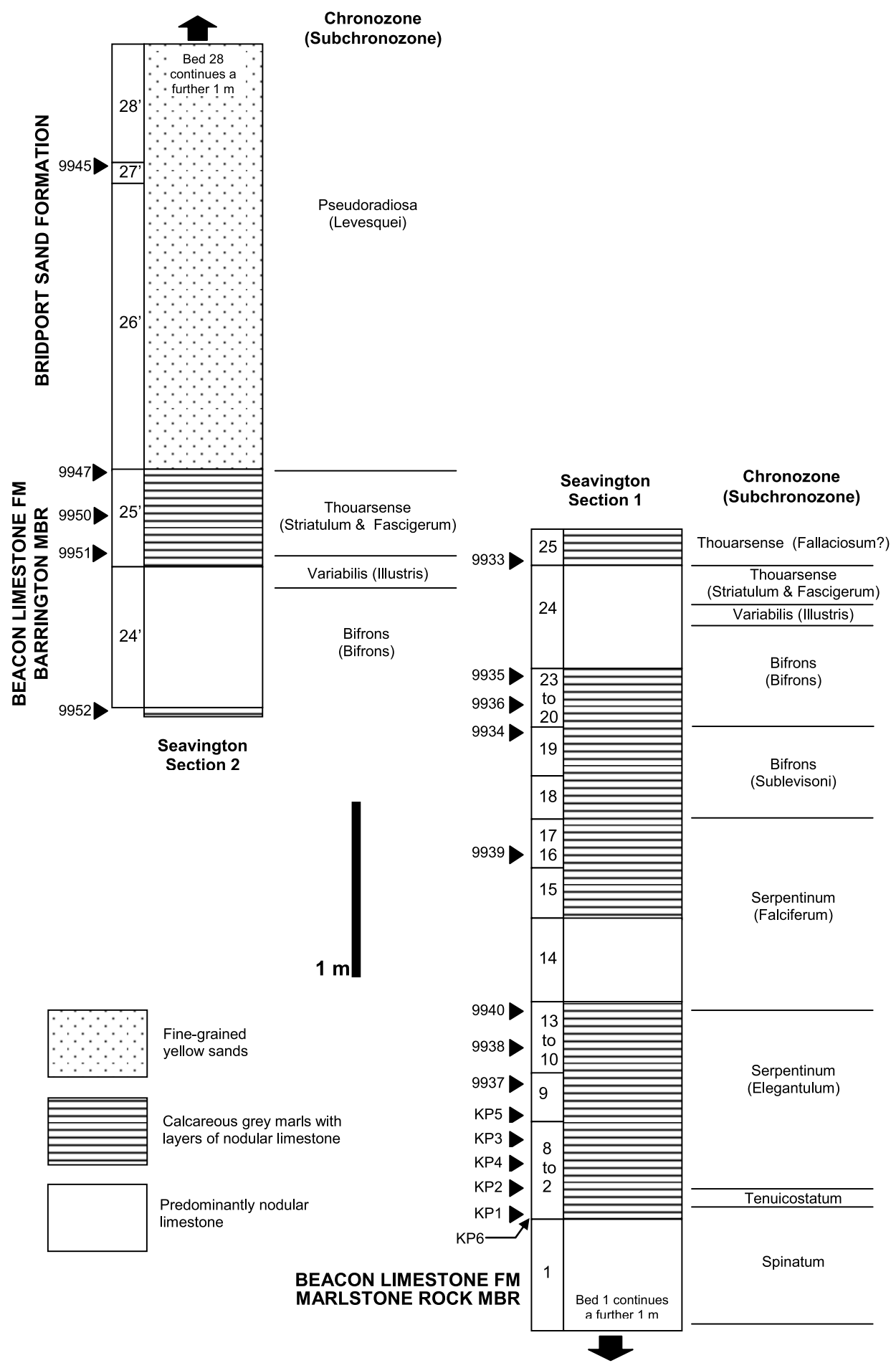

Fig. 2. Lithology, ammonite biostratigraphy and sampled levels from the Barrington and Seavington composite sections.

\section{HISTORY OF RESEARCH IN THE ILMINSTER DISTRICT}

The 'Middle' and 'Upper Lias' Junction Bed in Somerset (now formalized as the Beacon Limestone Formation, Table 1, (Cox et al., 1999) has long been known as a rich source of fossils. In particular, ammonites and brachiopods are abundant, and also well-preserved vertebrate and insect remains are also known. In addition, a rich microfauna and -flora have now been recovered. A local collector, Charles Moore, amassed a large representative collection of fossils, which are now housed in the Bath Geology Museum. He described the rocks of the small building-stone quarries surrounding the town of Ilminster and his publications are now classic (Moore, 1853, 1866). An associate, H. B. Brady, studied the foraminifera Moore had obtained and published an 


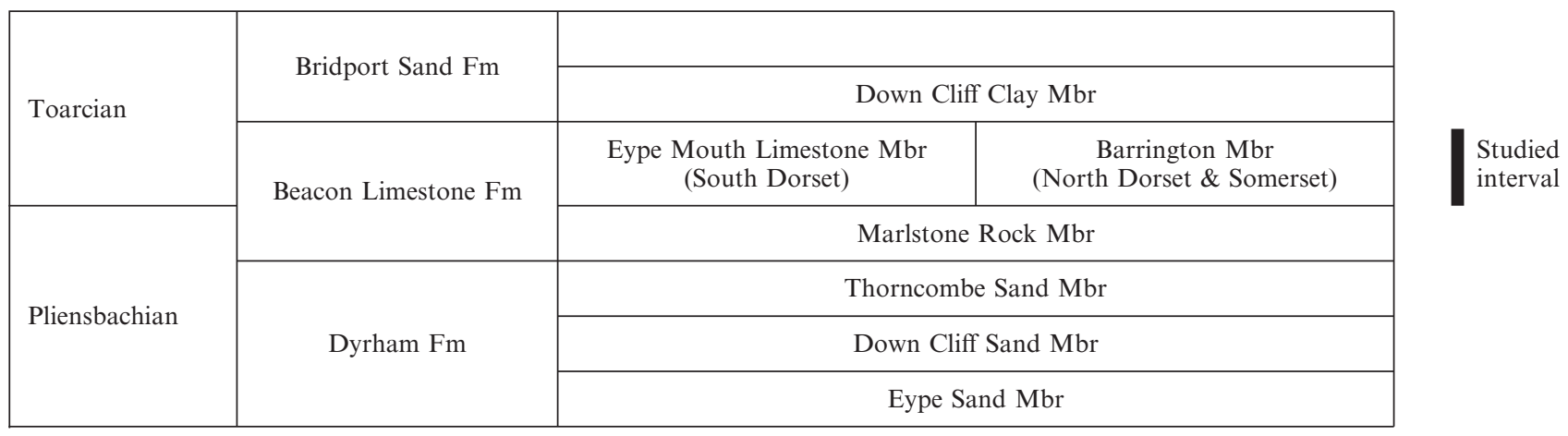

Table 1. Lithostratigraphy of the late Pliensbachian to Toarcian interval in SW England.

important early work (Brady, 1867; with a preliminary note in 1865 , Brady's foraminiferal collection is now housed in Charles Moore's collection at the Bath Museum (P. Copestake, pers. comm.).

Much later, excavations associated with farm buildings at Barrington, northeast of Ilminster, created renewed interest in the 'Junction Bed'; not least because 'upwards of 1000 specimens' had been collected (Hamlet, 1922; Pringle \& Templeman in Buckman, 1922). Spath had also recorded adjacent localities (in Buckman, 1922), but these sites and those at Barrington were largely obscured by the time the Geological Survey remapped the area between 1931 and 1946. The related memoir nevertheless contains the best summary of relatively recent exposures (Wilson et al., 1958). Since then it appears that only one other complete section has been seen, in a reservoir excavation near Stocklinch (Howarth in Cope et al., 1980: 54). The same work also provides a chronostratigraphical correlation of the Pliensbachian and Toarcian parts of the 'Junction Bed'. The Barrington section was reviewed by Howarth (1992) and elements of the ammonite fauna were figured in the associated monograph.

\section{LITHOSTRATIGRAPHY}

The 'Middle' and 'Upper Lias' Junction Bed (sensu Wilson et al., 1958, after Woodward, 1887) in Dorset and Somerset was consolidated into a single formation by Cox et al. (1999): the Beacon Limestone Formation (with the type section designated as Thorncombe Beacon on the Dorset Coast). The formation comprises two distinct units. The lower member, termed the 'Marlstone' by Moore (1853; after Wm Smith, 1817) and stabilized by Cox et al. (1999) as the Marlstone Rock Member, comprises calcarenitic bioclastic limestones, with occasional lenses of sandy or calcarenitic marl. In south Dorset this unit is rarely more than $0.6 \mathrm{~m}$ thick (Howarth in Cope et al., 1980, Column P1), but thickens locally to around $6 \mathrm{~m}$ in the Ilminster district (Howarth in Cope et al., 1980, Column P2).

The Marlstone Rock Member is overlain, in south Dorset, by between $0.5 \mathrm{~m}$ and $2.6 \mathrm{~m}$ of micritic limestones with occasional marl beds (Howarth in Cope et al., 1980, Column Tl - the Eype Mouth Limestone Member of Cox et al. (1999). The clay content increases northwards and, in the Ilminster district, the upper sedimentary sequence is typified by an alternation of argillaceous, often concretionary, limestones and marls, varying between $0.5 \mathrm{~m}$ and $2.6 \mathrm{~m}$ in thickness (Howarth in Cope et al., 1980, Column T2; Table 1, this work). Buckman (1922: 45) termed these the 'Barrington Beds' and Cox et al. (1999) proposed the Barrington Member, after Bristow \& Westhead (1993). It is these interbedded marls and argillaceous limestones that are the focus of this paper.

The macrofauna of the Marlstone Rock Member is often abundant, and dominated by benthic fauna, especially brachiopods and bivalves. Belemnites are common at certain levels, whereas ammonites are rare. Where lithologies are suitable, rich assemblages of ostracods, foraminifera and calcareous nannofossils were recovered. In contrast, the Barrington Member yielded very abundant pelagic biotas, while benthic macrofaunas are generally uncommon. The former are dominated by ammonites, belemnites and calcareous nannofossils, while the latter include occasional brachiopods, bivalves, gastropods, crinoid fragments and ophiuroid ossicles. The most common remains are the spines and other fragments of echinoids. The benthic microfauna is, nevertheless, abundant and consists of abundant, diverse ostracods and foraminifera.

In Somerset and Dorset, frequent evidence of erosion within the Barrington Member includes intraclasts and derived, worn and planed-through ammonites (as noted by Hallam, 1967). Ferruginous and/or glauconitic staining is common, especially in West Dorset, where there is a remarkable lithological similarity to the Ammonitico Rosso of southern Europe (Hallam, 1967).

\section{CHRONOSTRATIGRAPHY AND STANDARD ZONATION (KNP)}

Although still in frequent use in Britain (e.g. Howarth, 1992; Callomon \& Cope, 1995), the standard ammonite zonation proposed by Howarth in Dean et al. (1961) and later used with modifications by the same author in Cope et al. $(1980,1992)$ has been superseded. Considerable recent work, particularly in France, Spain, Portugal and Germany, has facilitated the refinement of earlier schemes and the zonation described by Elmi et al. (1997) for the North West European Ammonoid Province (sensu Page, 1996) is therefore employed here, as reviewed by Page (2003). As discussed extensively elsewhere (e.g. Callomon, 1985; Page, 1995, 2003), Jurassic ammonite zones are chronozones, not biozones, and are used in this sense herein and are so-labelled to avoid ambiguity. Representative collections were deposited in the Somerset County Museum. 
(a) Upper Pliensbachian Stage - Spinatum Chronozone (Seavington section 1, beds 1-2; Barrington, Seavington Marlstone Rock Member, including Bed 1 (part), see Figure 2. The entire Marlstone Rock Member can be assigned to the Spinatum Chronozone, as Pleuroceras was recovered from the basal surface of Bed 1. In situ evidence suggests that the Apyrenum Subchronozone includes virtually the entire Bed 1, at least up to within $10-15 \mathrm{~cm}$ of the top; $P$. solare (Phillips) is present at this level. Additional records from this subchronozone include $P$. gigas Howarth (from in situ and loose specimens of the subchronozonal index, P. apyrenum (Buckman), itself). That the top of Bed 1 includes part of the Hawskerense Subchronozone is indicated by specimens of $P$. spinatum (Bruguière) and $P$. cf. hawskerense (Young \& Bird), both collected as loose specimens. Two other rare taxa were obtained from loose blocks of Bed 1, but it is not known precisely from which subchronozone they came. These two specimens are identified as Lioceratoides cf. serotinus (Bettoni) and Leptaleoceras leptum Buckman. The latter is now unique in Britain, the type and two paratypes of the species having been destroyed. This specimen has now been described and figured by Howarth (1992, p. 163-164, pl. 30, fig. 3).

(b) Lower Toarcian - Tenuicostatum Chronozone (Seavington section 1, Bed 3; Barrington, Bed 1 (part)-Bed 2). Although no positive identifications were possible, the poorly preserved dactylioceratids of Bed 3 include fine-ribbed forms comparable to the Tenuicostatum Chronozone species. A specimen of Tiltoniceras sp., collected from a loose block, supports an upper Semicelatum (II) Subchronozone age for Seavington Bed 3 (equivalent to the Semicelatum (I) Subchronozone of Subboreal areas: see Page, 1996, fig. 6). A similar age was suggested for Bed 2 at Barrington (=Howarth in Cope et. al., 1980 column T2). It would appear that the Tenuicostatum Chronozone is, therefore, either absent (represented by only a few reworked specimens) or highly condensed at Ilminster. Unfortunately no sediment samples were recovered from these intervals, making it impossible to confirm the age through micro-biostratigraphy.

(c) Lower Toarcian - Serpentinum Chronozone, Elegantulum Subchronozone (Seavington section 1, beds 4-12; Barrington, beds 3-11). The most abundant elements of the Elegantulum Subchronozone faunas at Seavington comprise macro- and microconchs of Harpoceras ex gr. serpentinum (Schlotheim). Dactylioceratids are common at certain levels; however, Cleviceras exaratum (Young \& Bird) is rare and known only from two loose specimens. No ammonites are known from Seavington section 1 , beds 4 and 5; these levels are provisionally included in the Exaratum Subchronozone, and may represent parts of the subchronozone apparently absent at Seavington but present at Barrington (i.e. Bed 3, the 'Leptaena Clay', and Bed 4, the 'Fish Bed').

(d) Lower Toarcian - Serpentinum Chronozone, Falciferum Subchronozone, (Seavington section 1, beds 13-16; Barrington beds 12-23). Dimorphic Harpoceras ex gr. falciferum (J. Sowerby) is abundant and characteristic microconchs including ' $H$. exiguum' (Buckman, 1928). Dactylioceratids are frequent, and are dimorphic, with macroconchs assignable to the morphogenus Nodicoeloceras (Buckman) and microconchs being typical Dactylioceras spp. Occasional Hildaites cf. levisoni (Simpson) are also present. (e) Middle Toarcian - Bifrons Chronozone, Sublevisoni Subchronozone (Seavington section 1, beds 17-19; Barrington, beds 24-26). The lower part of this subchronozone (beds 17-18) yields an abundant and distinct fauna, dominated by Hildoceras ex gr. sublevisoni Fucini, nodose dactylioceratids ('Nodicoeloceras' spp.) and common Dactylioceras sensu stricto. Rare specimens of Harpoceras aff. falciferum and a single Ovaticeras ovatum (Young \& Bird) were also recovered. The latter species had not previously been recorded south of the Midlands (i.e. Oxfordshire and Northamptonshire, etc.), but is common in North Yorkshire (Howarth, 1992; Page, 2004). The specimen of Ovaticeras ovatum was described and figured by Howarth (1992, p. 142-143, pl. 23, fig. 4). The higher part of the subchronozone contains abundant, but small $(c .1-2 \mathrm{~cm})$ Dactylioceras ex gr. commune (J. Sowerby) and rarer Hildoceras (including $H$. cf. lusitanicum Meister), Harpoceras and a lytoceratid. The Sublevisoni, Tethysi and Lusitanicum horizons (= zonules sensu Page, 1995) of the subchronozone of Elmi et al. (1997) are probably present, but are not yet clearly separable at Ilminster.

(f) Middle Toarcian - Bifrons Chronozone, Bifrons Subchronozone (Seavington section 1, beds 20-24, to $45 \mathrm{~cm}$ below top; Seavington section 2, Bed 24', lowest $75 \mathrm{~cm}$; Barrington, Bed 27, lower part). The upper beds yield abundant Dactylioceras, marls and an intraclastic pebble bed are recorded with occasional Hildoceras ex gr. bifrons (Bruguière), suggesting the Bifrons Horizon of Elmi et al. (1997). The basal horizon of this subchronozone, with $H$. apertum (Gabilly), is not yet proven at Seavington. The almost total absence of post-Sublevisoni Subchronozone dactylioceratids in Somerset is noteworthy; in southern England Hildoceras spp. dominate the assemblages, whereas in North Yorkshire the dactylioceratids Zugodactylites, Peronoceras and Catacoeloceras are frequently the commonest ammonites (Page, 2004). Peronoceras and Catacoeloceras do, however, occur very rarely in the district, for instance in the nearby lane section at Hurcot (Wilson et al., 1958: 56; pers. obs.); they were not recorded by Howarth (1992) at Barrington.

Bed 23 and, especially, the lower parts of beds 24 and 24', contains an abundance of Hildoceras semipolitum Buckman, and so correlates with the Semipolitum Horizon of Elmi et al. (1997). The single loose specimen of Catacoeloceras would have also come from this level. The latter genus was also recovered in situ at Hurcot, 5-10 cm below abundant Haugia (= Variabilis Chronozone). A single Harpoceras subplanatum (Oppel) was recovered from the lowest part of Bed 24, while several others were collected as loose specimens.

(g) Middle Toarcian - Variabilis Chronozone (Seavington section 1, Bed 24, c. 40-45 cm below top; Seavington section 2, c. 3-15 cm below top of Bed 24', Barrington, Bed 27, middle part): Rare specimens of Haugia spp. appear in the lower part of Bed 24, associated with abundant Hildoceras semipolitum Buckman, indicating the base of the Variabilis Chronozone sensu Elmi et al. (1997). At Seavington this zone is highly condensed, being only around $10-15 \mathrm{~cm}$ thick, and is characterized by a ferruginous layer with abundant ammonites, which are typically ferruginous-stained and have etched surfaces, or are enclosed in intraclastic or oncolitic pebbles. The fauna of the intraclastic band consists largely of Haugia ex gr. phillipsi (Simpson), with occasional Phymatoceras spp. proving the presence of the Illustris Subchronozone (Phillipsi Horizon). Immediately below this 
band, a single Haugia cf. variabilis (d'Orbigny) would suggest the preceding Variabilis Subchronozone (and Variabilis Horizon). The Vitiosa Subchronozone at the top of the Variabilis Chronozone is not recognized at Seavington.

(h) Upper Toarcian - Thouarsense Chronozone, including Striatulum-Fascigerum Subchronozones (Seavington section 1, Bed 24, from $30 \mathrm{~cm}$ below top, to top of bed; Seavington section 2, Bed 24', top $3 \mathrm{~cm}$, and basal part of bed 25'; Barrington, Bed 27, upper part). The base of the Thouarsense Chronozone is placed at the first occurrence of Grammoceras spp.; it is readily correlated at Seavington, where G. striatulum (J. de C. Sowerby) occurs in abundance, immediately above Haugia. The coarserribbed $G$. thouarsense (d'Orbigny) becomes dominant towards the top of bed 24. Additional records include rare Pseudopolyplectus bicarinatus (Zieten), Phymatoceras sp. and poorly preserved fragments, which may be either a grammoceratid (Pseudogrammoceras) or a phymatoceratid (Esericeras). There is presently insufficient in situ information to clearly separate the Thouarsense and the Fascigerum subchronozones or recognize the basal Bingmanni Subchronozone. Nevertheless, the possible Esericeras in the top $5 \mathrm{~cm}$ of Bed 24 may indicate the base of the Fascigerum Subchronozone (index: Esericeras fascigerum Buckman).

(i) Upper Toarcian - Thouarsense Chronozone, Fallaciosum Subchronozone? (Seavington section 1, bed 25; Seavington section 2, bed 25', except basal part.; Barrington, Bed 28). Howarth (in Dean et al., 1961: 482) drew the base of the Fallaciosum 'Subzone' at the first occurrence of Pseudogrammoceras, but later noted that the genus had subsequently been recorded lower, in the Variabilis 'Zone' (in Cope et al., 1980: 53). The base of the subchronozone is, therefore, drawn here at the replacement of Grammoceras-rich faunas by the Pseudogrammocerasdominated assemblages. Only one other genus appears to be associated with Pseudogrammoceras: a single poorly preserved Hudlestonia, in preservation typical of Bed 25'.

(j) Upper Toarcian - Pseudoradiosa Chronozone, Levesquei Subchronozone (Seavington section 2, beds 26' to 28'; Barrington, beds 29-32). A single ammonite fragment was recorded, as apparently coming from the Bridport Sand Formation at Seavington, from 'Bed' 27. The preservation of the specimen and the associated limestone fragments and belemnites suggest, however, that this level comprises fragments incorporated into periglacially moved 'material' and, therefore, has no value for stratigraphical correlation. Comparison with Barrington suggests that a Pseudoradiosa Chronozone, Levesquei Subchronozone age is likely for the in situ Bridport Sand Formation below (Bed 26). A non-sequence is, thus, present at the base of the formation, as indicated by the irregular and ferruginous-stained basal contact between beds 25 and 26, plus the absence of Dispansum Chronozone deposits - which are present at Barrington.

\section{MICROBIOSTRATIGRAPHY}

The microfossil biostratigraphy of the Late Pliensbachian and Toarcian stages is less well known than for the rest of the Lower Jurassic in Britain, largely as a result of problems of sedimentary facies development and lack of exposure. The two classic sequences of international importance are the coastal sections of Dorset and Yorkshire. In Dorset, the youngest Pliensbachian
(Spinatum Chronozone) is represented by the Marlstone Rock Member, while most of the Toarcian (Tenuicostatum to basal Levesquei chronozones) is composed of condensed limestones, which together comprise the 'Junction Bed', now designated the Beacon Limestone Formation (Cope et al., 1980: 53-54, fig. 10A, Column T1). The succeeding latest Toarcian sediments are represented by a decalcified sand facies (Bridport Sand Formation), which occurs throughout much of southwest England at different chronostratigraphical levels (Arkell, 1933, fig. 30; Davies, 1969). In contrast, the Yorkshire coast sequence is more argillaceous, with Pliensbachian shales and ironstones overlain by thick Toarcian shale and paper shales; however, the burial history of these rocks has resulted in a degree of lithification that does not facilitate the easy extraction of calcareous microfossils although they are clearly present at some horizons (Copestake \& Johnson, 1989). Over much of central England, the Upper Pliensbachian Marlstone Rock Formation commonly occurs as an ironstone, while the Toarcian is developed in a clay and shale facies that is poorly accessible except in boreholes and rarely represents the full stage (Cope et al., 1980, figs 10A-10B).

For reasons of sedimentary development and exposure, the biostratigraphy of the Pliensbachian/Toarcian boundary interval is poorly known in the UK. The exception to this is the Mochras Borehole, west Wales, which was cored throughout and penetrates one of the thickest Lower Jurassic sequences in Europe $(1305 \mathrm{~m})$, entirely within an argillaceous facies. Commercial wells generally provide an incomplete picture of the boundary interval (due to the rare occurrence of ammonite biostratigraphical evidence). For example, detailed micropalaeontological work was undertaken in the Fastnet and Celtic Sea basins (Ainsworth, 1986, 1987; Ainsworth \& Horton, 1986; Ainsworth et al., 1989c; Rutherford \& Ainsworth, 1989). We will refer to the Mochras sequence in our discussions below, despite the fact that, apart from the ostracods (Lord, 1978; Boomer, 1991; Boomer \& Whatley, 1992) little has been published about this important section (calcareous nannofossils Bown, 1987, p. 8, text-fig. 2; foraminifera - Johnson, 1977; Copestake \& Johnson, 1981, 1989).

Ainsworth et al. (1998a, b) provided a detailed summary of the microbiostratigraphy and lithostratigraphy of the offshore Wessex Basin. The Pliensbachian-Toarcian interval in the offshore, English Channel wells is developed as a significantly thicker and more complete section than that of the condensed limestones on the Dorset Coast. The occurrence of Upper Pliensbachian and Toarcian sediments, of a dominantly argillaceous nature, from Somerset is obviously of considerable interest. The sequence is only $23 \mathrm{~km}$ north of the Dorset coast but is very different from the Beacon Limestone Formation occurring at Thorncombe Beacon. Microfossil samples were studied in relation to the detailed survey of lithostratigraphy and ammonite biostratigraphy outlined above (and Appendix A). Figure 2 gives sample numbers in relation to the beds and Ammonite zonation recognized at Seavington. Figure 3 provides an indication of the overall pattern of changing diversity across all microfossil groups, together with indices of appearance and extinction rates. The biostratigraphical record for each fossil group is present separately in Figures 4-7.

Palynological preparations are housed in the collections of the British Geological Survey, Keyworth, Specimens figured by 
I. Boomer et al.
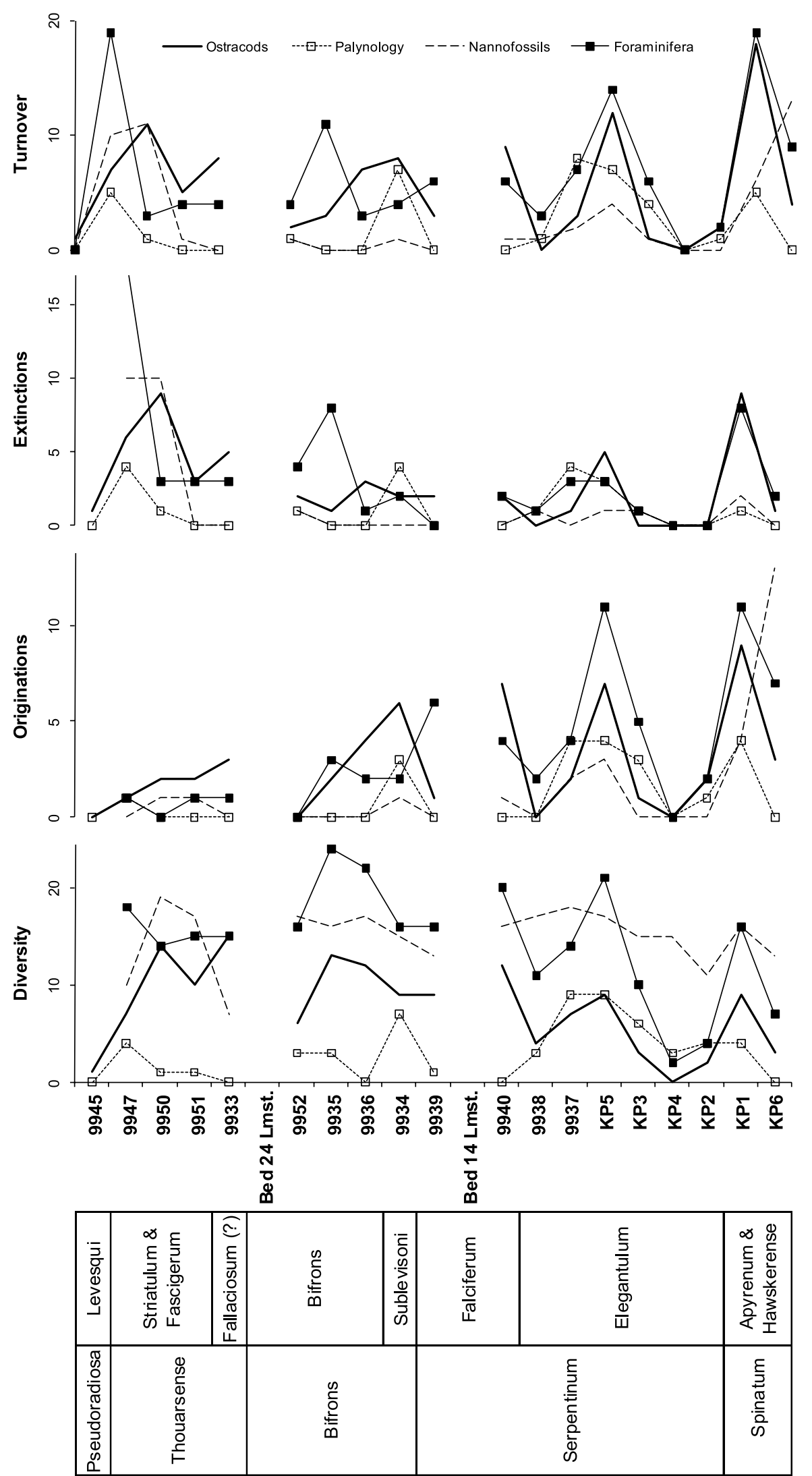

Fig. 3. Faunal diversity (number of species), species originations, extinctions and faunal turnover (originations + extinctions) in the Ilminster sequence. 


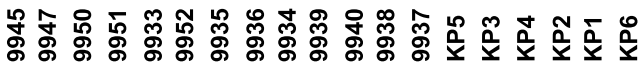

sпџัәә sпџорqечи6пәZ 92

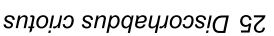

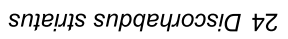
snquədns snบ?!!ou!ueว ع乙 ds ell!d!le6e^ 乙乙

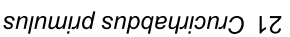
l.ds umınos!g oz un!qnp unınos!g 6 L !Клер umınos!g 81

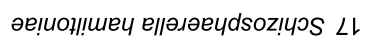
етерпюund sәp!оuобочдо $9 \mathrm{l}$ s!pued6 unłnos!g sl

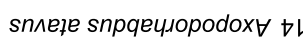
snınıed snpqeuı!qn $\perp \varepsilon$ -ds sollsellOS Zl

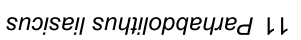
әеsue/ sny?!I0ג!W OL snıе|!! !!yney sп!6uщечро7 8 !!zoseq sп!6u!eчро7 L snssedo snบџ!!op!də10 9 sn^eo snบ!!||ор!daגo G -ds sninoKieo $t$ !!su!ud sn!uosng $\varepsilon$ unnou unınos!g 乙 !!บou!! unınos!g ।

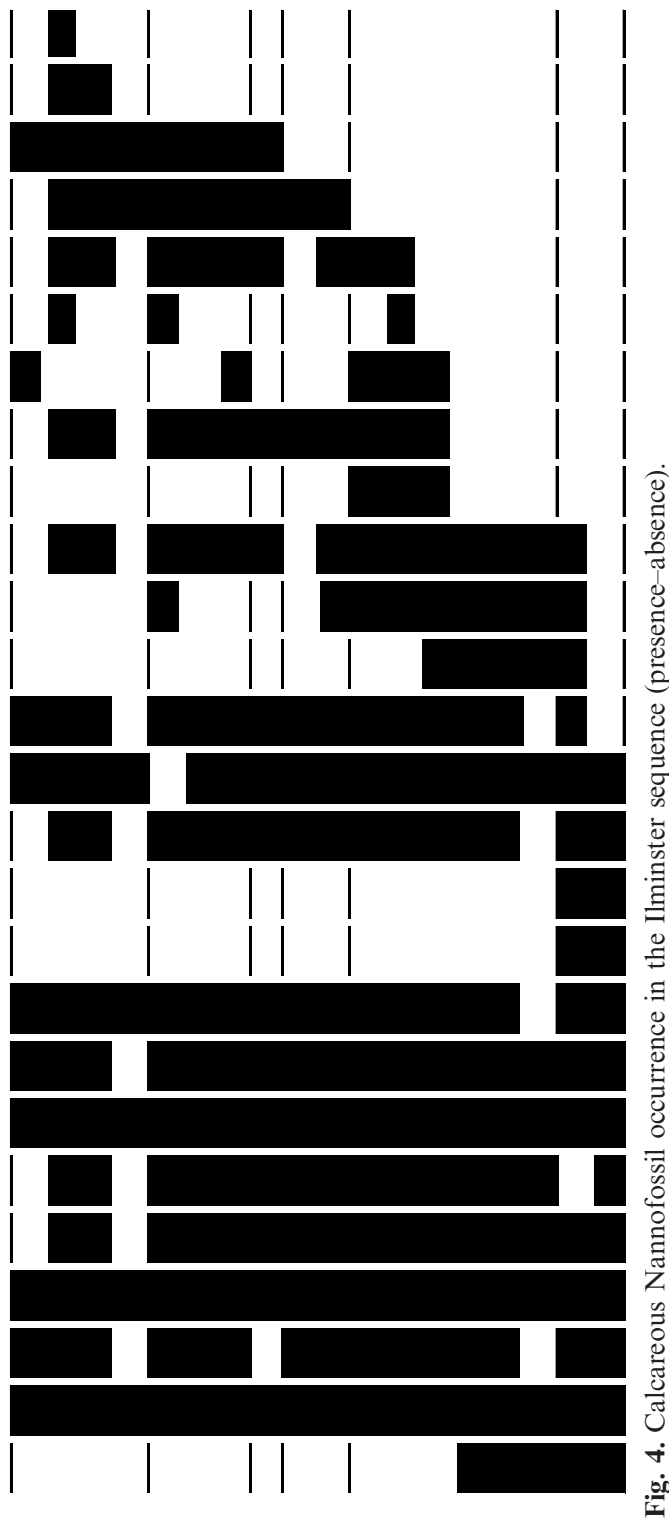

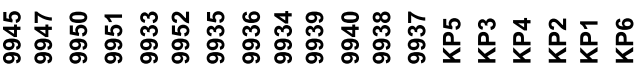

\begin{tabular}{|c|c|c|c|c|c|c|c|}
\hline$\left|\begin{array}{l}\overline{3} \\
\overline{0} \\
0 \\
0 \\
0 \\
\unlhd\end{array}\right|$ & 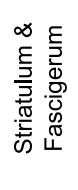 & 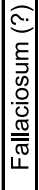 & 号 & 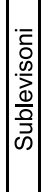 & 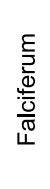 & 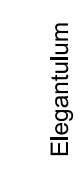 & 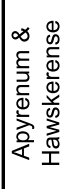 \\
\hline 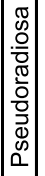 & 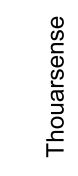 & & $\begin{array}{l}\text { 巳 } \\
\text { Oㄴ } \\
\text { : }\end{array}$ & & & 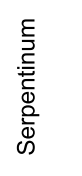 & $\begin{array}{l}\frac{E}{J} \\
\frac{1}{\pi} \\
\frac{.}{0} \\
\text { की }\end{array}$ \\
\hline
\end{tabular}



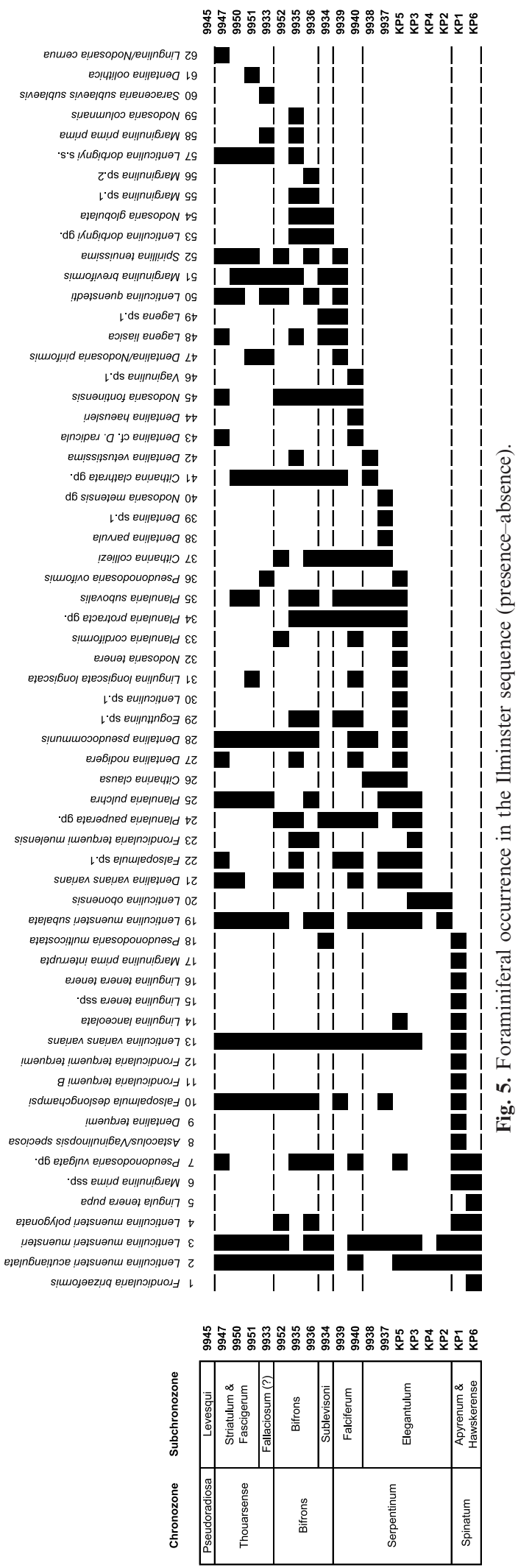
Pliensbachian-Toarcian microfossils, Ilminster

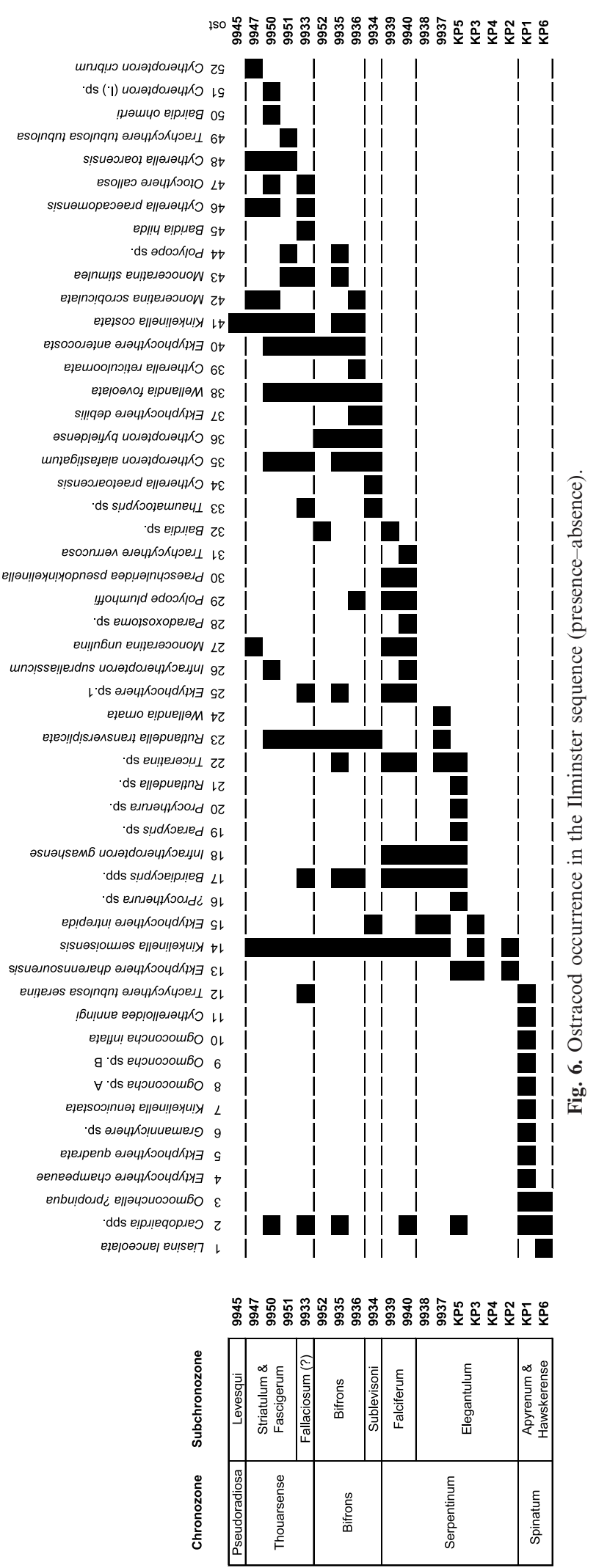


Chronozone Subchronozone

\begin{tabular}{|c|c|}
\hline Pseudoradiosa & Levesqui \\
\hline \multirow{3}{*}{ Thouarsense } & $\begin{array}{c}\text { Striatulum \& } \\
\text { Fascigerum }\end{array}$ \\
\cline { 2 - 2 } & Fallaciosum (?) \\
\hline \multirow{4}{*}{ Serpentinum } & Bifrons \\
\cline { 2 - 2 } & Sublevisoni \\
\cline { 2 - 2 } & Falciferum \\
\cline { 2 - 2 } & $\begin{array}{c}\text { Elegantulum } \\
\text { Spinatum }\end{array}$ \\
\hline
\end{tabular}

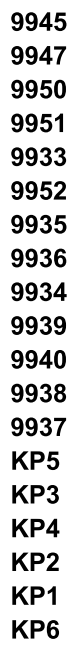

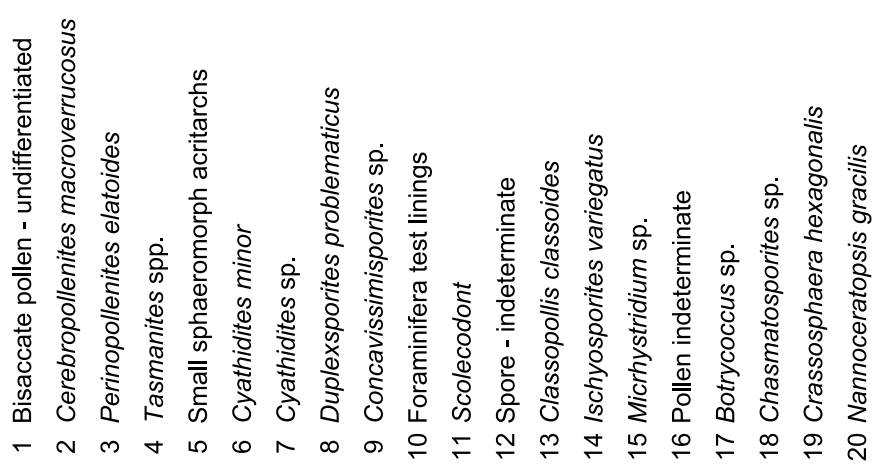

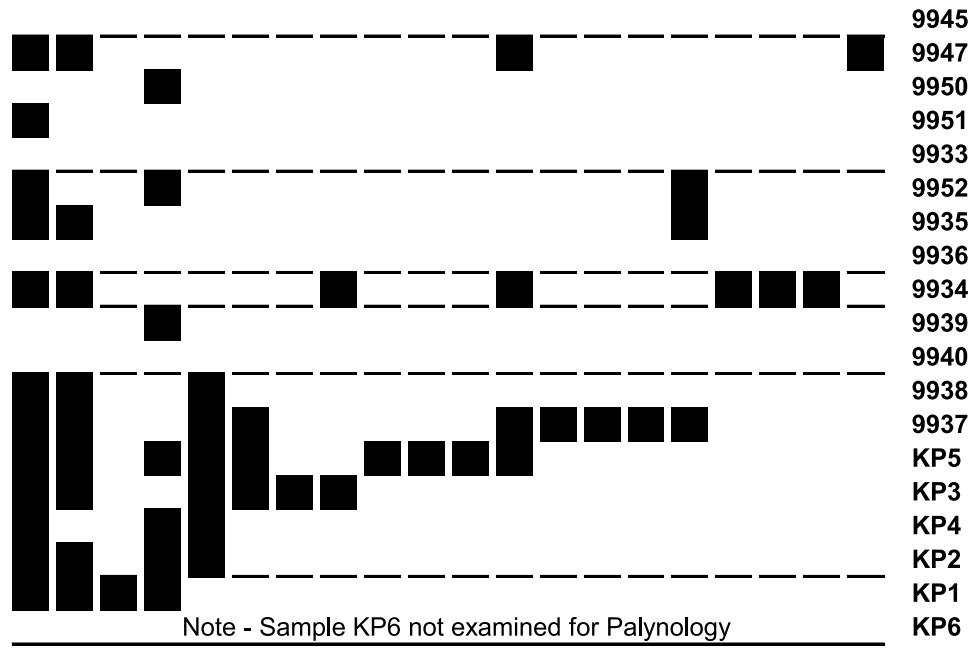

Fig. 7. Palynological occurrence in the Ilminster sequence (presence-absence).

Boomer (1992) are housed at the Natural History Museum, London, and all other material is held by University College London. The paper is presented with a view to establishing major faunal events and biostratigraphical ranges of microfossils through the sequence at Ilminster; occurrences are therefore given simply as presence-absence.

\section{Calcareous nannofossils}

The Upper Pliensbachian to Lower Toarcian interval is of great interest as it records the transition from earliest Jurassic nannofloras dominated by murolith coccoliths, such as Parhabdolithus liasicus Deflandre, Mitrolithus elegans Deflandre and Crucirhabdus primulus Prins, to late Early Jurassic/early Middle Jurassic nannofloras dominated by placolith coccoliths, such as Similiscutum spp., Biscutum novum (Bown), Lotharingius hauffii Grün \& Zweili and L. sigillatus (Bown). This interval also includes the diversification of the Biscutaceae coccolith group with the appearance of forms such as Biscutum grande Bown, B. finchii Crux, Discorhabdus striatus Moshkovitz \& Ehrlich and Sollasites spp., and the development of radical morphologies, for example, Calyculus spp. and Carinolithus superbus Deflandre. In contrast, the Late Toarcian was a time of evolutionary quiescence.

Eighteen of the nineteen Ilminster samples yielded diverse, abundant and well-preserved nannofossil assemblages (Fig. 4). The dominant species are Biscutum novum, Crepidolithus crassus Deflandre, Lotharingius hauffii and L. sigillatus and, together with the occurrence of Axopodorhabdus atavus (Bown), Bussonius prinsii (Bown), Calyculus spp., Crepidolithus impontus (Grün et al.) and Sollasites spp., they represent assemblages characteristic of uppermost Pliensbachian-Toarcian age throughout northwest Europe.

A number of species have first appearances and last occurrences within the section and these are of biostratigraphical interest. The presence of Mitrolithus jansae (Wiegand) and Parhabdolithus liasicus (last occurrences, Spinatum Chronozone) with Crepidolithus impontus (first appearance in Spinatum Chronozone) in the lowest samples (KP6, KP1) places them in the NJ5b Crepidolithus impontus NF (Nannofossil) Subzone (Bown et al., 1988; Bown \& Cooper, 1998), which has a SpinatumTenuicostatum Chronozone age range. The first appearance of Carinolithus superbus is slightly problematical as samples KP1 to 9938 all yield forms that are transitional from Calyculus to Carinolithus, the true end-member morphology is not observed until sample 9940 (Falciferum Subchronozone) which also has the first appearance of Discorhabdus striatus. These two datum levels are in close agreement with previously published results, e.g. Crux (1987), Bown et al. (1988) together these give their names to zones, NJ6 and 7.

The last occurrences of Biscutum finchii and B. grande in sample KP3 (Elegantulum Subchronozone) biscutacean genus, and its stratigraphical level is comparable with those reported by de Kaenel et al. (1986) and are similarly in agreement with Bown et al. (1996). The last occurrence of Similiscutum avitum de Kaenel \& Bergen in Sample KP4 (also Elegantulum Subchronozone) marks the disappearance of this earliest biscutacean genus, and its stratigraphic level is comparable with those reported by 
de Kaenel \& Bergen (1993) and de Kaenel \& Bergen, (1996). The typical bicyclic biscutacean coccoliths, Biscutum davyi Bown and Biscutum dubium Bown, have first appearances in samples KP1 and KP2, respectively. The former species has been reported only from the Ilminster section (Bown \& Cooper, 1989) and has a restricted range between samples KP1 and 9938. However, a similar coccolith, recorded here as Biscutum cf. B. davyi (having a very narrow or closed central area) in this study, ranges higher (to sample 9947). The top of the Lotharingius hauffii acme is recorded in the Bifrons to Thouarsense Chronozone interval, with abundances dropping from $40 \%$ to $9 \%$ in samples 9934 and 9936, and from 5\% to $0 \%$ in samples 9952 and $9951 ;$ L. hauffi comprises only $1 \%$ of the assemblages above this level. This interval sees a corresponding abundance increase in the Lotharingius sigillatus group.

\section{Foraminifera}

Abundant and diverse assemblages of foraminifera were recovered from the Pliensbachian-Toarcian interval at Ilminster (Fig. 5). Of the 19 samples studied, 18 yielded foraminifera. Sample 9945 from the Bridport Sand Formation (formerly the Yeovil Sands) in Seavington section 2, was barren; 62 species and subspecies were recognized from the remaining 18 samples. Foraminiferal diversity is approximately double that of the ostracods throughout the sequence (Fig. 3).

The character of the assemblages differs significantly from that of other British sections through the same interval, particularly at the oldest levels. Other studies of Pliensbachian-Toarcian foraminifera include those of Brady (in Moore, 1866 - Ilminster), Barnard (1950 - Northamptonshire), Adams (1957 Lincolnshire), Horton \& Coleman (1977 - Leicestershire), Coleman (1982 - Winterborne Kingston Borehole, Dorset), and Copestake \& Johnson (1981, 1989 - included the Mochras Borehole, west Wales) and Ainsworth et al. (1998a). In all of these areas the foraminiferal faunas contain arenaceous and miliolid elements, as well as the ubiquitous lagenine forms. In the northern North Sea this interval is marked by an almost wholly arenaceous fauna (Nagy, 1985), whereas onshore Britain and in western Europe, the faunas are more mixed. The uppermost part of the Pliensbachian (Spinatum Chronozone) is rarely microfossiliferous when developed in Marlstone Rock facies, while the Late Toarcian Down Cliff Clay Member on the Dorset Coast (and also present offshore in the Wessex Basin) yields a diverse assemblage of largely calcareous foraminifera (Copestake \& Johnson, 1989).

In areas where the Spinatum Chronozone is represented by argillaceous sediments, such as the Mochras Borehole, North Sea and Yorkshire Coast, foraminiferal assemblages are often well represented (P. Copestake, pers. comm.). Mochras is marked by an influx of Ophthalmidium and Spirillina (Copestake \& Johnson, 1989). Early Toarcian foraminiferal assemblages are dominated by Reinholdella species, a pattern which persists into the Serpentinum Chronozone. Considerable faunal turnover takes place in that zone and there is a marked appearance of arenaceous and miliolid forms. Many of the plexa originating in the Pliensbachian and earlier become extinct at this level, allowing many new species to subsequently appear (Bifrons Chronozone and younger). Thereafter the fauna takes on a more Middle Jurassic aspect, a trend also seen in the ostracods. The assemblages found at Ilminster differ from this general pattern in that they are exclusively hyaline in nature and, with the exception of rare occurrences of Spirillina tenuissima Gümbel, are entirely composed of members of the Suborder Lagenina. Certain markers seen elsewhere, such as the Reinholdella influx in the Tenuicostatum Chronozone, are not recorded at Ilminster due to the lack of samples from this interval. The lack of any miliolid and agglutinating taxa at Ilminster may indicate a primary environmental control.

The predominant genera comprise Lenticulina, Planularia and Citharina. Members of the Lenticulina muensteri Roemer plexus are common throughout the Seavington sections and form the main part of the background fauna. A number of events are of stratigraphical significance. First, the influx of Lenticulina obonensis (Cubaynes) in samples KP2 to KP3, a species which has been recorded only once before in Britain, by Brady (1865) from the same area under the name of Planularia cornucopiae Brady. Ruget (1982, p. 66) described L. obonensis from the Early Jurassic of Spain, ranging through the Tenuicostatum and Serpentinum chronozones. However, it has a more restricted range at Ilminster, where it occurs in great abundance in the lower part of the Serpentinum Chronozone.

A second stratigraphically important species of Lenticulina is L. dorbignyi Roemer. At Mochras this taxon first appears close to the top of the Crassum (=Bifrons, this work) Subchronozone, Bifrons Chronozone (Copestake \& Johnson, 1989) and has an identical first appearance here. A primitive morphotype (as L. dorbignyi gp) has an earlier first appearance lower, within the Sublevisoni Subchronozone, Bifrons Chronozone. Such forms have not been recognized elsewhere. This early morphotype generally has palmate later chambers while the ornament is much less organized than that of Lenticulina dorbignyi s.s. This ancestral form has its last occurrence immediately after the true L. dorbignyi s.s. first appears and is, therefore, considered to be an evolutionary antecedent and not a phenotypic variant.

Extinction levels within the Marginulina prima plexus provide useful stratigraphical markers and three subspecies are present at Ilminster. Marginulina prima spinata Terquem was recovered in the two stratigraphically lowest samples (KP6, KP1). Horton \& Coleman (1977, p. 10) give this subspecies an extinction level within the Exaratum Subchronozone in the Winterborne Kingston Borehole, whereas at Ilminster it is restricted to samples of Spinatum Chronozone age. Copestake \& Johnson (1989) noted the species as having a total range from the Upper Sinemurian to the Lower Toarcian, although their top occurrence in the Wessex Basin is given as only Upper Pliensbachian. Marginulina prima interrupta Terquem co-exists with $M$. prima spinata in the Spinatum Chronozone, possessing a similar extinction level. The third subspecies recorded, M. prima prima Terquem, occurs much higher in the section, in samples 9935 and 9933 (Bifrons-Thouarsense Chronozone age). The presence of Lingulina tenera pupa Terquem and L. tenera tenera in the basal two samples also places them as Spinatum Chronozone. The Lingulina tenera plexus finally becomes extinct at this level (KP1) and, as discussed above, the large extinction rate at this level is in part due to the condensed nature of the sequence with two major extinction events (end Pliensbachian and Tenuicostatum-Serpentinum boundary) 'compressed' into a 
single event. A number of key disappearances and first appearances are recorded by Copestake \& Johnson (1989) at the Pliensbachian-Toarcian boundary. The boundary is succeeded in many areas by 'Reinholdella'-dominated assemblages, reflecting major environmental changes. The nature and degree of these changes varies depending on the palaeogeographical and palaeodepth settings.

The genus Citharina is also abundant in the Ilminster sections. Two species are particularly common, C. clathrata Terquem and $C$. colliezi (Terquem), both appearing at approximately the same level towards the top of the Elegantulum Subchronozone (samples 9937, 9938). Citharina clathrata in particular is very abundant throughout the upper part of the Serpentinum and Bifrons chronozones. Copestake \& Johnson (1989) recorded the first British appearance of $C$. clathrata at Mochras in the Apyrenum Subchronozone, Upper Pliensbachian; however, it is not widespread below the Serpentinum Chronozone of the Lower Toarcian. Citharina colliezi occurs from the base of the Tenuicostatum Chronozone but, as with $C$. clathrata, only becomes widely distributed through the English Midlands within the Serpentinum Chronozone. This sudden influx of sixteen Citharina forms is a very distinctive event in the Ilminster succession and may be a useful marker for the Serpentinum Chronozone.

The Ilminster sequence has yielded a diverse assemblage of calcareous benthic foraminifera with no evidence of the agglutinating or miliolid forms known to be common in contemporaneous sequences elsewhere in the UK and its continental shelf, particularly at Mochras and the Yorkshire Coast (Copestake \& Johnson, 1989). The bulk of the sequence at Ilminster can be correlated with foraminiferal zone FJ9 (Ainsworth et al., 1998a) from the Wessex Basin/English Channel area, while a comparison with the zonation of Copestake \& Johnson (1989) indicates an equivalence to their zones JF12b to JF15. Zone JF16 is present on the basis of ammonite evidence, but the marker foraminiferal species, Nodosaria regularis ssp. A (Terquem) and Palmula tenuistriata (Franck), are absent at Ilminster.

\section{Ostracoda}

British Lower and Middle Toarcian ostracods have been described from the East Midlands (Bate \& Coleman, 1975), on the basis of which an ostracod biozonation was proposed for that interval. Park $(1987,1988)$ included a review of Pliensbachian ostracods from the Dorset coast in her review of Early Jurassic ostracod biostratigraphy from southern Britain and the southern North Sea. However, there does not seem to be any stratigraphical overlap between those records and the present study. Subsequent work (Boomer, 1992) included a taxonomic review of the ostracod assemblages recovered at Ilminster as well as a study of Lower Jurassic ostracods from the Mochras Borehole, west Wales (Boomer, 1991); preliminary results for the upper part of that sequence were published by Lord (1978). Ostracods have also been described from Pliensbachian to Aalenian sediments from exploration wells offshore south of Ireland (Ainsworth, 1986, et seq.) and the Wessex Basin (Ainsworth et al., 1998a).

The sections at Ilminster represent an important time in the evolution of early Jurassic ostracods. It was during this period that the Suborder Metacopina (ranging from the Silurian to the early Toarcian) became extinct, freeing biotopes that were filled following an evolutionary radiation within the superfamily Cytheracea. The reasons so far put forward for the demise of this otherwise successful group are well documented (Lord, 1982; Boomer et al., 2008). It is known that their disappearance corresponds with the widespread/global sea-level highstand during the earliest Toarcian (Tenuicostatum-Serpentinum boundary), a period which included an oceanic anoxic event and a globally recognized carbon isotope excursion (Hesselbo et al., 2000). Boomer et al. (2008) discussed the demise of this group in detail.

The assemblage of metacopine ostracods in the lowest two samples (Fig. 6) KP1 and KP6, Spinatum Chronozone, is quite distinct (note that sample KP6 was not available when the ostracods from Ilminster were first published by Boomer, 1992). These specimens belong to the genera Ogmoconcha and Ogmoconchella. Within the former genus are examples of the morphological group referred to as the 'vallate-Ogmoconcha' genus Hermiella; these have in the past been referred to as 'Tethyan' forms of the genus Ogmoconcha, due to their occurrence in the sediments of southern Germany, Portugal, Italy, North Africa, etc. (Malz, 1975; Maupin \& Vila, 1976; Maupin, 1977; Exton, 1979; Lord in Farinacci et al., 1979; Boutakiout et al., 1982; Boomer et al., 1998). Within the UK, these forms were recorded only from Ilminster (Boomer, 1992), the Mochras Borehole (Boomer, 1991) and offshore Ireland (Ainsworth, 1987).

The assemblage from sample KP1 is also similar to those recorded from the Apennines by Lord (in Farinacci et al., 1979) and comparable to samples recovered from the Wessex Basin (Ainsworth et al., 1998a) and Djebel Zaghouan, Tunisia (A. Lord, pers. obs.).

Sample KP1 includes the youngest record of both Cytherelloidea anningi Lord, although only one specimen was recovered, preserved partly pyritized, unlike the glassy to translucent calcite preservation for most other taxa. A few poorly preserved (pitted, abraded and weakly pyritized) specimens of Ektyphocythere quadrata Boomer \& Lord were also recorded. These two species are more commonly recorded from the earlier Margaritatus Chronozone of the Upper Pliensbachian and they are probably reworked. The ostracod assemblage from sample KP1 (assessed as Spinatum Chronozone on sparse ammonite evidence) bears a great similarity to those described from the late Tenuicostatum Chronozone of the Mochras Borehole. The occurrence within this sample of some heavily 'pitted' specimens mentioned above suggests that some reworking may have occurred at this level.

The succeeding sample (KP2) introduces a species which has previously only been described from its type locality in Morocco (ranging from 'early to mid-Toarcian'), Ektyphocythere dharennsourensis Boutakioult et al. has a distinctive outline and strong sexual dimorphism. This species continues to sample KP5; only in sample KP3 are the male dimorphs present. The nature of the hinge and of the anterior marginal pore canals suggest a possible ancestral position with respect to the genus Praeschuleridea, which occurs in the younger part of the section. The resemblance between these earliest Toarcian examples and contemporary assemblages described from North Africa, suggests a possible palaeoceanographical link at this time.

While some of the species recorded by Bate \& Coleman (1975) were found at Ilminster, others are absent, i.e. species of 
Procytherura, Eucytherura and Camptocythere. Direct biostratigraphical correlation between the present material and the East Midlands is not possible due to the absence at Ilminster of two of the zonal fossils designated by Bate \& Coleman (i.e. Camptocythere toarciana Bate \& Coleman and Kinkelinella persica Bate \& Coleman, both described in that work). The ranges of the two remaining zone fossils described by those authors accord well with the ranges recorded at Ilminster (see Fig. 6, Ektyphocythere intrepida Bate \& Coleman and E. debilis Bate \& Coleman). It should be noted that the ranges of these last two species, although apparently concurrent in both the East Midlands and Somerset, are much shorter than their total ranges recorded in the Mochras Borehole. This is also true for many of the species recorded from the other two sites.

In summary, samples KP1 to KP5 contain an ostracod fauna that suggests a strong palaeoceanographical link with parts of southern Europe and North Africa during the latest Pliensbachian?-earliest Toarcian. Sample KP1 contains an assemblage which may indicate reworking; indeed, some samples higher up in the section also include badly etched specimens (also possibly indicative of erosion/reworking). With only a few exceptions, there is considerable similarity between the present ostracod material (Serpentinum and Bifrons chronozones) and those described by Bate \& Coleman (1975) from the Lower and Middle Toarcian of the East Midlands. The ostracod assemblages at Ilminster can be correlated with the uppermost part of zone OJ8 and all of Zone OJ9 of the English Channel (Ainsworth et al., 1998a).

\section{Palynomorphs}

The samples yielded a disappointingly sparse, and generally poorly preserved, palynoflora (Fig. 7). In the past, coeval strata from southwest England have yielded diverse, wellpreserved palynomorph assemblages (Woollam \& Riding, 1983; Ainsworth et al., 1998a). However, the zone of weathering at Ilminster may have been especially well developed; alternatively the paucity of palynomorphs may be due to oxidation during, or soon after, deposition. Whatever the primary cause, it is clear that the palynological remains within the Ilminster sequence are of limited environmental and biostratigraphical application.

Of the taxa that were recorded, miospores numerically dominate the productive samples; gymnospermous pollen grains occur in greater numbers than pteridophytic spores. The miospore assemblages are characteristic of the early to middle Jurassic, with few taxa of biostratigraphical significance within this broad interval. The occurrence throughout of the pollen grain Cerebropollenites macroverrucosus Schultz is indicative of a post-Sinemurian age. All the spores identified are relatively long ranging within the Jurassic (Srivastava, 1987).

A single dinoflagellate cyst specimen was recovered from the Ilminster samples. Nannoceratopsis gracilis Alberti was found in sample 9947; this taxon ranges from the Upper Pliensbachian to Bajocian and is widespread throughout the northern hemisphere (Woollam \& Riding, 1983). Clumps of small (18-23 $\mu \mathrm{m}$ in diameter) sphaeromorph acritarchs were recorded from samples KP2 to 9938 (Serpentinum Chronozone, Elegantulum Subchronozone). This association is characteristic of the Lower Toarcian of Europe (see Loh et al., 1986; Riding, 1987). Of the few species recognized, only one (Nannoceratopsis gracilis) can be correlated with the Dinocycst Zonation of the English Channel/Wessex basin by Ainsworth et al. (1998a). That species occurs only in a single sample (9947, top of the Thouarsense Chronozone) and gives an indication of a Late Pliensbachian to Late Toarcian age.

\section{Microbiostratigraphical summary}

The microbenthos (ostracods and foraminifera) yielded wellpreserved and diverse assemblages of marine aspect. Both groups show generally good agreement with assemblages from elsewhere in the UK in terms of stratigraphical ranges. The main exception to this is the absence of Spirillinid and Reinholdellid foraminiferal assemblages, which may be due in part to the absence of significant Tenuicostatum Chronozone development at Ilminster; however, a primary environmental cause cannot be ruled out. It must be noted that the lack of microbiostratigraphical samples from the Tenuicostatum Chronozone undoubtedly generates an unusually abrupt, apparent 'extinction' horizon.

The microplankton records varied between well-preserved, diverse calcareous nannofossil assemblages and low-diversity pollen, spore and dinocysts assemblages. The nannofossil species present are generally long ranging and there is little stratigraphical value in these records, although there are a few key events in the lower part of the sequence associated with faunal turnover in the Pliensbachian-Toarcian boundary interval (disappearance of Mitrolithus jansae and Parhabdolithus liasicus). The palynomorph record was particularly disappointing, especially since it was during the Pliensbachian and Toarcian that dinocysts diversified prior to becoming very important during the later Jurassic. The palynomorphs from Ilminster, although sparse, are consistent with the ammonite biostratigraphy. The association of terrestrially derived elements (miospores) with indigenous marine forms (microplankton) indicates a marine environment of deposition throughout but with a degree of terrestrially-sourced input. The occurrence of Tasmanites (generally associated with high levels of organic productivity) is sporadic throughout the sequence but most concentrated in the lower part of the Serpentinum Chronozone, correlating with marked faunal turnover in the lowest part of the sequence.

\section{DISCUSSION OF THE PLIENSBACHIAN-TOARCIAN SEQUENCE AT ILMINSTER}

The Pliensbachian-Toarcian biotic turnover was not one of the 'Big Five' mass extinctions (Newell, 1967; Jablonski \& Chaloner, 1994), but it was nevertheless an important event and was recognized as such by Hallam (1961). For benthic microfauna (foraminifera and ostracods), the significance of the Pliensbachian-Toarcian biotic turnover in the Paris Basin was demonstrated in range charts published by Apostolescu \& Bourdon (1956, tables II-IV), Apostolescu (1959, table 1) and in the 'Colloque sur le Lias' (1961). Subsequent work throughout Europe, has documented the microfaunal and -floral turnover in much greater detail, for example Riegraf (1985) for southern Germany. However, very high-resolution microbiostratigraphical analysis of this interval remains elusive for palaeoenvironmental and facies reasons.

The Ilminster sections reveal a Late Pliensbachian-Toarcian sequence (Spinatum to Pseudoradiosa ammonite chronozones) 
with good macro- and microfossil assemblages. The interval is rarely exposed inland, but is especially important in the area of southwest England, since, on the Dorset coast only $23 \mathrm{~km}$ away, this time period is represented largely by the condensed limestones of the Beacon Limestone Formation, a remanié carbonate deposit. This formation is generally difficult to assess for detailed biostratigraphical purposes because of hiatuses, lowsedimentation rates and reworking. The micropalaeontology of condensed limestones are often restricted to thin-sections work and acid-digests (palynomorphs usually occur in low densities in limestones). At Ilminster the occurrence of interbedded calcareous marls has provided an insight in the local calcareous and organic-walled micropalaeontology of this period.

The Ilminster sequence is more calcareous than the full Toarcian record observed in the Mochras Borehole but, more significantly, lacks the bituminous shale facies usually encountered in the Early Toarcian throughout much of western Europe and, thus, provides diverse, well-preserved benthic microfossils. In Yorkshire, the Wessex Basin, Paris Basin, southern Germany, northern Switzerland, etc., early Toarcian (typically the earliest part of the Serpentinum Ammonite Chronozone) bituminous shale sequences occur (e.g. Posidonienschiefer Formation of southern Germany), reflecting anaerobic or dysaerobic bottom conditions with consequent paucity or absence of benthos. In such areas the ranges of benthic species are interrupted, with certain species recolonizing as 'Lazarus taxa' (Wignall \& Benton, 1999) after the 'oxygen-minimum event', and the pattern of temporary absence and reappearance reflects the differing tolerances of individual species to such reduced-oxygen conditions. In many cases, extinction events can be linked to the change in bottom-water environments. Ilminster is a section of considerable importance and our samples yielded calcareous and organic-walled plankton, calcareous benthos and terrestrially derived spores and pollen.

One disappointing aspect of the Ilminster section was our inability to study the Pliensbachian-Toarcian boundary interval in detail. Adequate evidence exists to show that the late Spinatum Chronozone, Upper Pliensbachian, is present but the samples from around the boundary were poorly constrained and it is apparent that the Tenuicostatum Chronozone is probably all but absent. This boundary and the lower Toarcian interval is of interest because of macro- and microfaunal turnover around this period, with particular significance for the ostracods as it includes the extinction of the Suborder Metacopina (Boomer et al., 2008), an important Palaeozoic group that had thrived to this point, surviving both the end-Palaeozoic and the TriassicJurassic boundary extinction events. This major faunal event associated with the Early Jurassic is now considered to have occurred not at the Pliensbachian-Toarcian boundary, but at the Tenuicostatum-Serpentinum (or Falciferum) Chronozone boundary (Boomer et al., 2008), neither of which are recorded in detail at Ilminster. Significant faunal turnover is recognized in most groups at Ilminster, with 11 foraminiferal taxa and 11 ostracod taxa not surviving into the Toarcian.

The changing faunal record at Ilminster is presented not just as biostratigraphical range charts (Figs 4-7) but also as combined records of faunal diversity, species appearance, species extinction and overall faunal turnover (appearance plus extinction for any given sample) in Figure 3. Inevitably such plots will have 'edge effects', i.e. the oldest samples often have (apparent) highest rates of 'appearance' and the youngest samples the (apparent) highest rates of 'extinction' where long-ranging taxa continue beyond the interval studied. Nevertheless, some important observations can be made.

The most striking section in the plots of microbiostratigraphical change (Fig. 3) is the marked diversity decrease, with associated increased faunal turnover, between samples KP1 and KP2, i.e. the Pliensbachian-Toarcian 'boundary'. It must be remembered, however, that the lack of any microfossil samples of Tenuicostatum Chronozone age means that the interval between the two aforementioned samples spans a period from latest Spinatum to early Serpentinum Chronozones. This period includes both the widely recognized end-Pliensbachian and early Toarcian extinction events seen in many groups (e.g. Copestake \& Johnson, 1989; Boomer et al., 2008). Following the diversity decrease within the early part of the Serpentinum Chronozone at Ilminster there is a second diversity rise and fall accompanied by marked faunal turnover (Elegantulum Subchronozone, Serpentinum Chronozone). This is most noticeable in the benthos (ostracods and foraminifera), with the plankton being little affected, suggesting that this primarily reflects changes in the bottom-water conditions. Given the temporal framework, this second event may be related to the further development of dysaerobic conditions known from elsewhere in Europe during the early Toarcian. It is also significant that this interval of marked faunal turnover (broadly equivalent to the Toarcian Oceanic Anoxic Event across Europe) coincides with the occurrence of the sphaeromorph actritarch horizons. These are known to be strongly associated with Toarcian carbon-isotope excursions (and Oceanic Anoxic Events) and are even recorded in abundance in the Mochras Borehole where bottom-water conditions remained oxic through the Early Toarcian (van de Schootbrugge et al., 2005).

\section{CONCLUSIONS}

The sediments and microfossils indicate deposition in relatively shallow-water, marine conditions, well-oxygenated and largely unaffected by the dysaerobia seen elsewhere in the major depositional basins of Europe at this time.

The poor palynoflora, with the presence of only one dinocyst species, some miospores and Pteridophytes indicates a depositional position in mid-shelf conditions, with some influence of land-derived material. However, all other macro- and microfossil groups studied reflect a normal marine shelf environment.

The calcareous nannofossils have provided a useful biostratigraphical correlation with other sites in northwest Europe (cf. Bown, 1987); however, the assemblages are not comparable with the exceptional Paris Basin Toarcian nannofloras described by Goy (1981).

The foraminiferal assemblages yielded important Toarcian records of diverse and well-preserved assemblages, which provides supplementary documentation of ranges for a number of important species groups (data used by Copestake \& Johnson, 1989); assemblages are unusual in that they contain exclusively hyaline forms.

The ostracods are represented by a remarkably good Toarcian record without interruption by bituminous facies. The diversification of cytheracean taxa following the demise of the 
metacopines in earliest Toarcian is clearly displayed but, unfortunately, sampling resolution covering the metacopine extinction event itself is poor and the event cannot be elucidated in detail at this locality.

\section{ACKNOWLEGEMENTS}

MRM partnership, Consulting Engineers (Taunton) and Balfour Beatty Construction Limited kindly allowed access to the site, at all stages of construction. The assistance of Mr R. A. Croft (Somerset County Council) in the initial arrangements for access is acknowledged gratefully. Miss E. C. R. Ryan assisted in the early stages of the survey. M. K. Howarth (Natural History Museum, London) generously discussed the ammonite identifications. The authors are indebted to P. Copestake (Merlin Energy) and C. Ruget (Lyon) for discussion and advice concerning Lower Jurassic foraminifera during the early stages of this work. Financial support is acknowledged gratefully from the Leverhulme Trust (ARL, PRB), Natural Environment Research Council (KNP) and University College London (FMDL, IDB). The contribution by J. B. Riding is published with the permission of the Director, British Geological Survey (NERC). The authors are indebted to G. Warrington (BGS Keyworth) for his critical comments on an early version of the manuscript. The extensive reviews of Phil Copestake and Nigel Ainsworth have improved the manuscript greatly. Thanks to them and to John Gregory for their tireless efforts.

\section{APPENDIX A: DESCRIPTION OF SECTIONS}

Roadworks on the Ilminster bypass intersected the outcrop of the Ilminster Beacon Limestone Formation for a distance of around $700 \mathrm{~m}$, north to northwest of Seavington St Michael (Fig. 1). No single exposure revealed a continuous section and, therefore, it was necessary to correlate the beds seen in various small pits and cuttings in order that a more complete record could be made. Section 1, as described below (Fig. 2), is therefore a composite, based on observations of around $100 \mathrm{~m}$ of this exposure. Lateral variation was nevertheless great and it was necessary to record the westernmost exposure separately (Section 2).

Section 1 - Composite, based on excavations and cuttings centred on Grid Ref. ST 406157; north of Seavington St Michael. Bed numbers also marked on Figure 2.

\section{BEACON LIMESTONE FORMATION; BARRINGTON MEMBER}

UPPER TOARCIAN - THOUARSENSE CHRONOZONE, FALLACIOSUM SUBCHRONOZONE?

25 Clay, brown-weathered; passes up into a loam subsoil. Lowest $15 \mathrm{~cm}$ contains a discontinuous band of irregularly sized limestone concretions, composed of pale-grey-coloured argillaceous micrite. Belemnites and small bivalves common, also Pseudogrammoceras sp.

UPPER TOARCIAN - THOUARSENSE CHRONOZONE, THOUARSENSE-FASCIGERUM SUBCHRONOZONES

24 Limestone, argillaceous micrite, weathering a pale-buff colour. A $5 \mathrm{~cm}$ thick seam of grey marl is present $5 \mathrm{~cm}$ below the top of the unit, and a 1-2 $\mathrm{cm}$ seam at around $7 \mathrm{~cm}$ above the base. A band at around $30-40 \mathrm{~cm}$ below the top is iron-stained and contains intraclasts and eroded ammonites; the latter frequently have etched surfaces covered with a dark ferruginous veneer. Faunal records from Bed 24 include belemnites. From the top $5 \mathrm{~cm}-$ Grammoceras cf. striatulum (J. de C. Sowerby), G. thouarsense (d'Orbigny), Esericeras or Phlyseogrammoceras sp.; from 5-10 $\mathrm{cm}$ below the top (= marl seam) - G. cf. striatulum, $G$. thouarsense; from $15 \mathrm{~cm}$ below top $-G$. striatulum, cf. Pseudogrammoceras sp., Pseudopolyplectus bicarinatus (Zieten); from $20 \mathrm{~cm}$ below top - G. striatulum, G. sp. cf. Phymatoceras sp. (poorly preserved), Pseudogrammoceras or Esericeras sp.; from $30 \mathrm{~cm}$ below top - G. striatulum.

UPPER TOARCIAN - VARIABILIS CHRONOZONE From $35 \mathrm{~cm}$ below the top of Bed 24 (=ferruginous band) - Haugia phillipsi (Simpson) (abundant), Phymatoceras sp., Hildoceras semipolitum Buckman (fragment).

LOWER TOARCIAN - BIFRONS CHRONOZONE, BIFRONS SUBCHRONOZONE From $45 \mathrm{~cm}$ below top of Bed $24-H$. semipolitum (abundant); from $55 \mathrm{~cm}$ below top (= marl seam) - H. semipolitum; from $60 \mathrm{~cm}$ below top (basal $7 \mathrm{~cm}$ ) $-H$. semipolitum, (abundant), Hildoceras aff. bifrons (Bruguiere), Harpoceras subplanatum (Oppel).

23 Marl, grey, with occasional ammonites and 'Mummien', i.e. ammonites forming the core of oncolitic pebbles, $H$. semipolitum present.

22 Ferruginous band, full of small (1-2 cm) irony pebbles, and with occasional ochreous-stained c. $20 \mathrm{~cm}$ in-situ? ammonite fragments: Hildoceras cf. bifrons and a lytoceratid present.

21 Marl, grey, with Hildoceras sp. and a lytoceratid.

20 Limestone, argillaceous micritic, weathering a pale buff colour; grey when fresh. In one or two bands, with a marl seam between: Dactylioceras sp. and $H$. cf. bifrons present.

LOWER TOARCIAN - BIFRONS CHRONOZONE, SUBLEVISONI SUBCHRONOZONE

19 Nodular argillaceous limestones and grey marl; consisting of irregular, thin lenticles, in three

Total for Bed 24 $60-75 \mathrm{~cm}$.

$$
\begin{array}{r}
7 \mathrm{~cm} \\
10 \mathrm{~cm} \\
0-5 \mathrm{~cm} \\
7-15 \mathrm{~cm}
\end{array}
$$

$25-30 \mathrm{~cm}$ bands, with marl between. Dactylioceras ex gr. commune (J. Sowerby) (abundant small specimens) and occasional Hildoceras cf. sublevisoni Fucini present; also Harpoceras sp. cf. falciferum (J. Sowerby), a lytoceratid and a pectenid bivalve. 
16 Marl, grey, full of small nodules (1-2 cm), especially towards the top; Harpoceras falciferum [M] and $[\mathrm{m}]$ abundant.

15 Irregular lenticles and scattered smaller nodules of argillaceous limestone in grey marl $-H$. falciferum present.

14 Limestone, soft argillaceous micritic, thinly and irregularly bedded - pale greyish-buff colour. $H$. falciferum common; also contains Hildaites cf. levisoni, Dactylioceras sp.

13 Marl, grey, with irregular lenticles of argillaceous micrite; $H$. falciferum present.

LOWER TOARCIAN - SERPENTINUM CHRONOZONE, ELEGANTULUM SUBCHRONOZONE

12 Limestone, argillaceous micritic; thin nodular bed with irregular surfaces.

11 Marl, grey, with small $(<1 \mathrm{~cm})$ limestone nodules.

10 Limestone, argillaceous micritic, similar to bed 12.

9 Marl, grey; with small limestone nodules $(<1 \mathrm{~cm})$ concentrated around a band towards the middle of the bed. This band yields Dactylioceras sp. The marl below contains Harpoceras serpentinum (Reinecke) and Dactylioceras sp.

8 Limestone, argillaceous micrite; irregular band, with common ammonites on upper surface $(H$. serpentinum).

$7 \quad$ Marl, grey; H. serpentinum present.

6 Band of irregularly sized argillaceous micrite nodules (up to $5 \mathrm{~cm}$ in diameter).

5 Marl, grey; greenish tinged.

4 Marl, grey; laminated \& sandy, seams rich in shell debris. Basal 5-10 cm rusty coloured, occasional irony nodules. The junction with Bed 3 is marked by a thin ochreous seam.

\section{LOWER TOARCIAN - TENUICOSTATUM CHRONOZONE}

3 Limestone, concretionary argillaceous micrite, in part sandy. Dactylioceras sp. present on base of bed.

\section{MARLSTONE ROCK MEMBER}

UPPER PLIENSBACHIAN - SPINATUM CHRONOZONE

$2 \quad$ Sand, calcareous and marly; with occasional concretions of bioclastic and sandy limestone (sandy calcarenite). Pleuroceras ex gr. hawskerense (Young \& Bird) present; also abundant large belemnites and occasional brachiopods.

1 Limestone; hard, sandy and bioclastic calcarenite; pale brownish-buff coloured, frequently with ferruginous staining. Contains occasional calcitic ooliths and abundant brachiopods, belemnites and bivalves. Occasional lenticles of softer sandy-marl occur at various levels in the unit; one, around $25 \mathrm{~cm}$ below the top, was associated with a large Pleuroceras gigas (Howarth). P. cf. solare is locally common, $c$. 15-20 cm below the top of bed 1. Additional faunal records include $P$. spinatum (Bruguiere), P. cf. hawskerense (Young \& Bird), P. solare (Phillips), P. apyrenum (Buckman), Lioceratoides serrinotu, Leptaleoceras lepturn Buckman, Tetrarhynchia tetrahedra (J. Sowerby), Lobothyris punctata (J. Sowerby), Pseudopecten aequivalvis (J. Sowerby), Entolium sp., Chlamys sp., Oxytoma sp., Pleuromya sp. and a large pleurotomariid gastropod. Excavated blocks suggest the total thickness of bed 1 is around $2-2.5 \mathrm{~m}$. The basal part has an irregular contact with bluish-grey sandy silts; this layer contains abundant belemnites, brachiopods and Pleuroceras sp.

Section 2 - Cutting on north side of bypass on brow of Boxstone Hill [Grid ref ST 402155].

\section{?QUATERNARY}

\section{BRIDPORT SAND FORMATION}

28' Sand, rusty weathering; passes into subsoil with lenses of limestone brash.

27' Band of widely spaced limestone nodules, composed of pale-grey argillaceous micrite. Belemnites and shell fragments common, also a fragment of Pseudogrammoceras sp.

UPPER TOARCIAN - ?PSEUDORADIOSA CHRONOZONE, LEVESQUEI SUBCHRONOZONE

26' Sand, rusty weathering, with pale grey patches containing some mud. Rusty at base.

BEACON LIMESTONE FORMATION; BARRINGTON MEMBER

UPPER TOARCIAN - THOUARSENSE CHRONOZONE, FALLACIOSUM SUBCHRONOZONE

c. $2 \mathrm{~m}$

$0-5 \mathrm{~cm}$

$1.6 \mathrm{~m}$ 
25' Clay, dark-grey; with bands of lenticular limestone concretions composed of grey argillaceous

micrite. Near the junction with the Bridport Sand Fm., black streaks are present in the clay. At

$7-15 \mathrm{~cm}$ below the top of the bed, a band of nodules is associated with abundant belemnites and a

fragment resembling Pseudogrammoceras sp.

UPPER TOARCIAN - THOUARSENSE CHRONOZONE, THOUARSENSE-FASCIGERUM SUBCHRONOZONES

The basal $10-15 \mathrm{~cm}$ of $25^{\prime}$ contains abundant, usually fragmentary, ammonites and belemnites,

also small $(<1 \mathrm{~cm})$ limestone nodules - Grammoceras striatulum, G. thouarsense and

Pseudogrammoceras sp. occur.

24' Limestone, argillaceous micrite - grey when unweathered - with abundant ammonites, belemnites and shell-fragments. Divisible into three units: - (c) topmost $2-3 \mathrm{~cm}$; contains abundant

Grammoceras cf. striatulum, belemnites and fragments of a thin-shelled (?Inoceramid) bivalve. The

Total for upper surface of this layer has a ferruginous coating and occasionally passes laterally into a 5-10 cm thick ochreous band.

UPPER TOARCIAN - VARIABILIS CHRONOZONE

(b) 3-15 cm below top of 24'; a layer full of derived and broken ammonites, typically encased in intraclastic pebbles or oncolites (i.e. 'Mummien'); Haugia ex gr. phillipsi is abundant. Some intraclasts have decayed and ochreous cores.

(a) lowest c. $75 \mathrm{~cm}$ of Bed 24', contains abundant Hildoceras semipolitum. Some specimens have an epifauna consisting of small (5-10 mm long) serpulids and oysters. Haugia $\mathrm{cf}$. variabilis (d'Orbigny) present $30 \mathrm{~cm}$ below top of bed 24', with abundant Hildoceras semipolitum.

LOWER TOARCIAN - BIFRONS CHRONOZONE, BIFRONS SUBCHRONOZONE

Hildoceras semipolitum abundant without Haugia present in lowest $50 \mathrm{~cm}$ of 24'

Marl seam, grey; with small nodules. Thickness not known (base of section).

\section{Manuscript received 1 June 2007 \\ Manuscript accepted 1 March 2009}

\section{REFERENCES}

Adams, C.G. 1957. A study of the morphology and variation of some Upper Lias foraminifera. Micropaleontology, 3: 205-226.

Ainsworth, N.R. 1986. Toarcian and Aalenian Ostracoda from the Fastnet Basin, offshore south-west Ireland. Geological Survey of Ireland, Bulletin, 3: 277-336.

Ainsworth, N.R. 1987. Pliensbachian Ostracoda from the Fastnet Basin, offshore south-west Ireland. Geological Survey of Ireland, Bulletin, 4: $41-62$.

Ainsworth, N.R., Braham, W., Gregory, F.J., Johnson, B. \& King, C. 1998a. A proposed latest Triassic to earliest Cretaceous microfossil biozonation for the English Channel and its adjacent areas. In: Underhill, J.R. (Ed.), Development, Evolution and Petroleum Geology of the Wessex basin. Geological Society, London Special Publication, 133: $87-102$.

Ainsworth, N.R., Braham, W., Gregory, F.J., Johnson, B. \& King, C. 1998b. The lithostratigraphy and biostratigraphy of the latest Triassic to earliest Cretaceous of the English Channel and its adjacent areas. In: Underhill, J.R. (Ed.), Development, Evolution and Petroleum Geology of the Wessex basin. Geological Society, London, Special Publication, 133: 103-164.

Ainsworth, N.R. \& Horton, N.F. 1986. Mesozoic micropalaeontology of exploration well Elf 55/30-1 from the Fastnet. Basin, offshore south-west Ireland. Journal of Micropalaeontology, 5: 19-29.

Ainsworth, N.R., O'Neill, M. \& Rutherford, M.M. 1989. Jurassic and Upper Triassic biostratigraphy of the North Celtic Sea and Fastnet Basins. In: Batten, D.J. \& Keen, M.C. (Eds), Northwest European Micropalaeontology and Palynology. British Micropalaeontological Society/Ellis Horwood, London, 1-44.

Apostolescu, V. 1959. Ostracodes du Lias du Bassin de Paris. Revue de l'Institut Français du Pétrole, XIV: 795-826.

Apostolescu, V. \& Bourdon, M. 1956. Corrélations dans le Lias marneux des Causses Majeurs. Revue de l'Institut Français du Pétrole, XI: $439-451$.

Arkell, W.J. 1933. The Jurassic System in Great Britain. Clarendon Press, Oxford, 681pp.

Barnard, T. 1950. Foraminifera from the Upper Lias of Byfield, Northamptonshire. Quarterly Journal of the Geological Society of London, 106: 1-36.
Bate, R.H. \& Coleman, B.E. 1975. Upper Lias Ostracoda from Rutland and Huntingdonshire. Bulletin of the Geological Survey of Great Britain, 55: 1-42.

Boomer, I.D. 1991. Lower Jurassic Ostracod biozonation of the Mochras Borehole. Journal of Micropalaeontology, 9: 205-218.

Boomer, I.D. 1992. Lower Jurassic Ostracods from Ilminster, Somerset, England. Journal of Micropalaeontoloy, 11: 47-64.

Boomer, I., Ainsworth, N.R. \& Exton, J. 1998. A re-examination of the Pliensbachian and Toarcian Ostracoda of Zambujal, west-central Portugal. Journal of Micropalaeontology, 17: 1-14.

Boomer, I., Lord, A.R. \& Crasquin Soleau, S. 2008. The demise of the Metacopina. Senckenbergana lethaea, 88: 47-53.

Boomer, I.D. \& Whatley, R.C. 1992. Ostracoda and dysaerobia in the lower Jurassic of Wales: the reconstruction of past oxygen levels. Palaeogeography, Palaeoclimatology, Palaeoecology, 99: 373-379.

Boutakiout, M., Donze, P. \& Oumalch, F. 1982. Nouvelles especes d'ostracodes du Lias Moyen et superieur du Jbel Dhar en Nsour (Rides Sud-Rifaines Maroc Septentrional). Revue de Micropaleontologie, 25: 94-104.

Bown, P.R. 1987. Taxonomy, evolution and biostratigraphy of late Triassic-early Jurassic calcareous nannofossils. Special Papers in Palaeontology, 38: 1-118.

Bown, P.R. \& Cooper, M.K.E. 1989. New calcareous nannofossils from the Jurassic. Journal of Micropalaeontology, 8: 91-96.

Bown, P.R. \& Cooper, M.K.E. 1998. Jurassic. In: Bown, P.R (Ed.), Calcareous Nannofossil Biostratigraphy. Chapman \& Hall/Kluwer, Dordrecht, Netherland, 34-85.

Bown, P.R., Cooper, M.K.E. \& Lord, A.R. 1988. A calcareous nannofossil biozonation scheme for the early to mid Mesozoic. Newsletters on Stratigraphy, 20: 91-114.

Brady, H.B. 1865. On the Foraminifera of the Middle and Upper Lias of Somersetshire. Report of the British Association for the Advancement of Science for 1864, 50: 1-12.

Brady, H.B. 1867. Foraminifera. In: Moore, C., On the Middle and Upper Lias of the south-west of England. Somersetshire Archaeological and Natural History Society Proceedings during the years 1865-6, 13: $119-245$.

Bristow, C.R. \& Westhead, R.K. 1993. Geology of the Evercreech Batcombe District (Somerset). British Geological Survey Technical Report, WA/93/89: 1-89.

Buckman, S.S. 1922. Jurassic chronology: II - Preliminary studies. Certain Jurassic strata near Eypemouth (Dorset): the Junction-Bed of 
Watton Cliff and associated rocks. Quarterly Journal of the Geological Society, 78: 378-436.

Callomon, J.H. 1985. The evolution of the Jurassic ammonite family Cardioceratidae. Special Papers in Palaeontology, 33: 49-90.

Callomon, J.H. \& Cope, J.C.W. 1995. The Jurassic Geology of Dorset. In: Taylor, P.D. (Ed.), Field Geology of the British Jurassic. Geological Society, London, 51-103.

Coleman, B.E. 1982. Lower and Middle Jurassic foraminifera in the Winterborne Kingston Borehole, Dorset. In: Rhys, G.H., Lott, G.K. \& Calver, M.A. (Eds), The Winterbourne Kingston Borehole, Dorset, England. Report of the Institute of Geological Sciences, 81(3): 82-88.

Colloque sur le Lias français 1960. 1961. Mémoires du Bureau de Recherches Géologiques et Minières, 4: 1-862.

Cope, J.C.W., Getty, T.A., Howarth, M.K., Morton, N. \& Torrens, H.S. 1980. A correlation of Jurassic rocks in the British Isles. Part One: Introduction and Lower Jurassic. Geological Society of London Special Report, 14: 1-73.

Cope, J.C.W., Ingham, J.K. \& Rawson, P.F. (Eds). 1992. Atlas of palaeogeography and lithofacies. Geological Society of London, Memoirs, 13: 1-153.

Copestake, P. \& Johnson, B. 1981. Jurassic Part 1. The Hettangian to Toarcian. In: Jenkins, D.G. \& Murray, J.W. (Eds), Stratigraphical Atlas of Fossil Foraminifera. British Micropalaeontological Society/ Ellis Horwood, London, 81-105.

Copestake, P. \& Johnson, B. 1989. The Hettangian to Toarcian (Lower Jurassic). In: Jenkins, D.G. \& Murray, J.W. (Eds), Stratigraphical Atlas of Fossil Foraminifera (2nd edn.). British Micropalaeontological Society/Ellis Horwood, London, 129-188.

Cox, B.M., Sumbler, M.G. \& Ivimey-Cook, H.C. 1999. A Formational Framework for the Lower Jurassic of England and Wales (Onshore Area). British Geological Survey Research Report, RR/99/01: 1-25.

Crux, J.A. 1987. Early Jurassic calcareous nannofossil biostratigraphic events. Newsletters in Stratigraphy, 17: 79-100.

Davies, D.K. 1969. Shelf sedimentation: an example from the Jurassic of Britain. Journal of Sedimentary Petrology, 39: 1344-1370.

Dean, W.T., Donovan, D.T. \& Howarth, M.K. 1961. The Liassic Ammonite Zones and Subzones of the North-West European Province. Bulletin of the British Museum (Natural History) Geology, 4: 435-505.

Elmi, S., Rulleau, L., Gabilly, J. \& Mouterde, R. 1997. Ammonites Toarcien. In: Cariou, E. \& Hantzpergue, P. (Eds), Biostratigraphie du Jurassique Ouest-Europeen et Mediterraneen, Bulletin Centre Recherches Elf Exploration Production Mémoire, 17: 25-36.

Exton, J. 1979. Pliensbachian and Toarcian microfauna of Zambujal, Portugal: systematic paleontology. Carleton University, Ottawa, Geological Paper, 79(1): 1-103.

Farinacci, A., Lord, A.R., Pallini, G. \& Schiavinotto, F. 1979. The depositional environment of the Domerian-Toarcian sequence of Strettura (Umbria). Geologica Romana, XVII(1978): 303-323.

Goy, G. 1981. Nannofossiles calcaires des Schistes Carton (Toarcien inferieur) du Bassin de Paris. Documents de la RCP 459. Museum National d'Histoire Naturelle, Paris, 86pp.

Hallam, A. 1961. Cyclothems, Transgressions and Faunal Change in the Lias of North-West Europe. Transactions of the Edinburgh Geological Society, 18: 124-174.

Hallam, A. 1967. An environmental study of the Upper Domerian and Lower Toarcian in Great Britain. Philosophical Transactions of the Royal Society London, H252: 393-445.

Hamlet, J. 1922. On sections in the Lias exposed in two quarries at Barrington. Proceedings of the Somerset Archaeological and Natural History Society, 67: 72-75.

Hesselbo, S., Gröcke, D.R., Jenkyns, H.C., Bjerrum, C.J., Farrimond, P., Morgans Bell, H.S. \& Green, O.R. 2000. Massive dissociation of gas hydrate during a Jurassic oceanic anoxic event. Nature, 406: 392-395

Horton, A. \& Coleman, B.E. 1977. The lithostratigraphy and micropalaeontology of the Upper Lias at Empingham, Rutland. Bulletin of the Geological Survey of Great Britain, 62: 1-12.

Howarth, M.K. 1992. The Ammonite Family Hildoceratidae in the Jurassic of Britain. Palaeontographical Society Monograph, 200pp.
Jablonski, D. \& Chaloner, W.G. 1994. Extinctions in the fossil record. Philosophical Transactions of the Royal Society, London, B344: $11-16$.

Johnson, B. 1977. Ecological ranges of selected Toarcian and Domerian (Jurassic) foraminiferal species from Wales. In: Schafer, C.T. \& Pelletier, B.R. (Eds), First International Symposium on Benthonic Foraminifera of Continental Margins - Part B. Maritime Sediments Special Publication No.1, 545-556.

de Kaenel, E. \& Bergen, J. 1993. New Early and Middle Jurassic coccolith taxa and biostratigraphy from the eastern proto-Atlantic (Morocco, Portugal and DSDP Site 547B). Eclogae Geologicae Helvetiae, 86: 861-907.

de Kaenel, E., Bergen, J.A. \& von Salis Perch-Nielsen, K. 1996. Jurassic calcareous nannofossil biostratigraphy of western Europe. Compilation of recent studies and calibration of bioevents. Bulletin de la Société Géologique de France, 167: 15-28.

Loh, H., Maul, H., Prauss, M. \& Riegel, W. 1986. Primary production, maceral formation and carbonate species in the Posidonia Shale of N.W. Germany. Mitteilungen aus dem Geologisch-Palaontologischen Institut der Universitat Hamburg, 60: 397-421.

Lord, A.R. 1978. Jurassic Part 1 (Hettangian-Toarcian). In: Bate, R.H. \& Robinson, E. (Eds), A stratigraphical index of British Ostracoda. British Micropalaeontological Society/Ellis Horwood, London, 189212

Lord, A.R. 1982. Metacopine ostracods in the Lower Jurassic. In: Banner, F.T. \& Lord, A.R. (Eds), Aspects of Micropalaeontology. Allen \& Unwin, London, 262-277.

Malz, H. 1975. Eine Entwicklungsreihe 'vallater' Ogmoconchen (Ostracoda) im S.-deutschen Lias. Senckenbergiana lethaea, 55: 484-503.

Maupin, C. 1977. Donnes micropaleontologiques nouvelles et precisions stratigraphiques sur le Lias du Kef Ben Chikr Bou Rouhou et du Kef Toumiette Nord (Chaine Calcaire Kabylenord du Constantinois Algerie). Revue de Micropaléontologie, 20: 91-99.

Maupin, C. \& Vila, J.-M. 1976. Microfossiles du Lias superieur au Djebel Youssof (Hautes Plaines Setillennes, Algerie). Revue de Micropaléontologie, 19: 162-165.

Moore, C. 1853. On the palaeontology of the Middle and Upper Lias. Proceedings of the Somerset Archaeological and Natural History Society, 3: 61-76.

Moore, C. 1866. On the Middle and Upper Lias of the southwest of England. Proceedings of the Somerset Archaeological and Natural History Society, 13: 119-245.

Nagy, J. 1985. Jurassic foraminiferal facies in the Statfjord area, northern North Sea. Journal of Petroleum Geology, 8: 273-295.

Newell, N.D. 1967. Revolutions in the history of life. In: Albritton, C.C. (Ed.), Uniformity and Simplicity: a symposium on the principle of the uniformity of nature. Geological Society of America, Special Papers, 89: 63-91.

Page, K.N. 1995. Horizons; Intra-Subzonal Units in Jurassic Ammonite Stratigraphy. Palaeontology, 38: 801-814.

Page, K.N. 1996. Mesozoic Ammonoids in Time and Space. In: Landman, N.H., Tanabe, K. \& Davis, R. (Eds), Ammonoid Palaeobiology. Plenum Press, New York, 855-794.

Page, K.N. 2003. The Lower Jurassic of Europe: its subdivision and correlation. Geological Survey of Denmark and Greenland Bulletin, 1: 223-259.

Page, K.N. 2004. A sequence of biohorizons for the Subboreal Province Lower Toarcian in northern Britain and their correlation with a Submediterranean Standard. Rivista Italianana di Paleontologia e Stratigrafia, 110: 109-114.

Park, S.-M. 1987. The ostracod Zones and Subzones of the Lower Jurassic in the southern North Sea Basin. Journal of the Paleontological Society, Korea, 3: 44-70.

Park, S.-M. 1988. Evolutionary lineages of some stratigraphically important taxa from the Lower Jurassic of North-West Europe. Journal of the Paleontological Society, Korea, 4: 110-118.

Riding, J.B. 1987. Dinoflagellate cyst stratigraphy of the Nettleton Bottom Borehole (Jurassic: Hettangian to Kimmeridgian), Lincolnshire, England. Proceedings of the Yorkshire Geological Society, 46: 231-266. 
Riegraf, W. 1985. Mikrofauna, Biostratigraphie und Fazies im Unteren Toarcium Südwestdeutschlands und Vergleiche mit benachbarten Gebieten. Tübinger Mikropaläontologische Mitteilungen, 3: 1-232.

Ruget, C. 1982. Foraminiferes du Lias moyen et superieur d'Obon. Geobios, 15: 53-91.

Rutherford, M.M \& Ainsworth, N.R. 1989. Micropalaeontological and stratigraphical recognition of the Triassic-Jurassic boundary in the North Celtic Sea \& Fastnet Basins. In: Batten, D.J. \& Keen, M.C. (Eds), Northwest European Micropalaeontology \& Palynology. British Micropalaeontological Society/Ellis Horwood, London, 45-59.

Smith, W. 1817. Strata identified by organized fossils. Pt. III. E. Williams, London, $118 \mathrm{pp}$

Srivastava, S.K. 1987. Jurassic spore-pollen assemblages from Normandy (France) and Germany. Geobios, 20: 5-79. van de Schootbrugge, B., McArthur, J.M., Bailey, T.R., Rosenthal, Y., Wright, J.D. \& Miller, K.G. 2005. Toarcian oceanic anoxic event: An assessment of global causes using belemnite $\mathrm{C}$ isotope records. Paleoceanography, 20, DOI: 10.1029/2004PA001102.

Wignall, P.B. \& Benton, M.J. 1999. Lazarus taxa and fossil abundance at times of biotic crisis. Journal of the Geological Society, London, 156: 453-456.

Wilson, V., Welch, F.B.A., Robbie, J.A. \& Green, G.W. 1958. Geology of the Country around Bridport and Yeovil. Memoirs of the Geological Survey of Great Britain, 239pp.

Woodward, H.B. 1887. The Geology of England and Wales (2nd edn.). Phillip \& Son, London, 257pp.

Woollam, R. \& Riding, J.B. 1983. Dinoflagellate cyst zonation of the English Jurassic. Institute of Geological Sciences Report, 83/2, 42pp. 